University of Ss. Cyril and Methodius, Skopje

Faculty of Philosophy

chausidis@gmail.com

\title{
ODYSSEUS' SHOOTING AN ARROW THROUGH AXES AS AN ACT OF COITUS AND HIEROGAMY
}

\begin{abstract}
The topic of this article is the described episode from the Odyssey in which Odysseus, after his long wanderings around the world, returns to Ithaca where he confirms his identity by shooting with a bow and arrow through 12 axes planted into the ground. The goal of the study is to reveal the character and semiotics of this act. The analysis begins with a presentation of the female aspects of the axe and especially of the double axe i.e. the labrys as a woman and a goddess. This is followed by an analysis of the arguments that point to the symbolic identification of these tools with the female genitalia and specifically - the equation of their handle opening with the vulva and uterus. Sufficient attention is also dedicated to the multiplication of the axes, based on several archaeological finds, as well as the symbolism of the bow and arrow, with special emphasis on the traditions that represent them as a symbol of the male principle. At the end, based on all the separately analyzed elements, a thesis is presented and argued that in the given period the mentioned act functioned as a ritual in which the archer entered a symbolic coitus with the female deity represented through the double axes. This procedure bore the character of hierogamy through which the man confirmed his masculinity, his legitimacy as a husband, as a companion (impregnator and son) of the Great Goddess and as ruler of the given land.
\end{abstract}

Key words. - Odyssey, Odysseus, hierogamy, axe, double axe, labrys, bow and arrow.

The incentive for this study is the famous episode from the Odyssey in which Odysseus, after many years of wandering around the world, returns to his palace in Ithaca where he confirms his own identify by shooting with a bow and arrow through 12 axes planted into the ground, one behind the other. ${ }^{1}$ Our main goal is to reveal and argue the female meaning of these axes, and with that - determine the very act of shooting arrows as a ritual with the character of hierogamy. We believe that, in addition to the stated goals, the analyzes carried out in our study will contribute in revealing the semiotics of the objects involved in the mentioned act, in general within the frames of archaic cultures, and in particular - within those from the territory of the Balkans and Macedonia. Primarily in relation to the axe, especially the

${ }^{1}$ (Homeri Odyssea 21). 
double axe i.e. labrys, but also occasionally regarding the bow and arrow.

The character and meaning of this episode i.e. the unusual act around which it revolves, has already been the subject of multiple studies. Most of them were focused towards the technical aspects of the described action i.e. the way in which it was performed and whether it was even possible, while the rest were focused on its philological aspects i.e. the precise meaning of the lexemes used in the verses. ${ }^{2}$ Thereby, the greatest dilemmas were caused by the word $\sigma \tau \varepsilon i \lambda \varepsilon i \eta$ ' which signifies the part of the axes through which Odysseus' arrow was to pass, which is finally interpreted not as the handle of an axe, but as the hole for the handle of an axe. ${ }^{3}$ Some of the researchers also touch on the meaning, i.e. the symbolism of the very act of this unusual shooting. I. Venedikov does that sporadically, studying a similar motif within South Slavic folk poetry in which a hero shoots a bow and arrow through a ring. He concludes that in both cases it is an act of marital significance, which in the songs is a prerequisite for marriage with the girl, and in the Odyssey - for the selection of Penelope's new husband. ${ }^{4}$ A similar conclusion is also reached by C. J. Russo, while analyzing analogous epic acts from some Eastern cultures in which various heroes shoot arrows through hoops, through the opening of a wheel or through objects in the shape of a boar's mouth, in order to marry the royal daughter, to restore their lost regal status and/or return their lost wife i.e. queen. ${ }^{5}$

Although the mentioned researchers do not concern themselves more specifically with the semiotics of the axes in Homer's epic, their interpretations give arguments in favor of the proposal that they are symbols of the woman, or even more precisely - symbols of the female genitalia. With that in mind, shooting through them acquires the meaning of a sexual act that needs to declare and emphasize the masculinity and potency of the archer, especially if we take into account the appropriate meaning of the bow and arrow as a symbol of the male principle and the phallus. ${ }^{6}$

In this article we will present arguments and analyzes in support of this hypothesis, which also goes in favor of the symbolic i.e. the ritual character of the mentioned act and its archetypal (transcultural and transhistoric) character. In doing so, we will dedicated special attention to the examples from the territory of Macedonia that would indicate the presence of these traditions outside the Aegean region, in other Balkan regions, and not only in the periods to which the Odyssey re-

\footnotetext{
2 Stanford 1949; Pocock 1961; Brain \& Skinner 1978; Russo 2004.

${ }^{3}$ Stanford 1949, 4, 5; Pocock 1961, 348 - 351; Russo 2004, 96, 97.

${ }^{4}$ Венедиков 1987, 63-67.

${ }^{5}$ Russo 2004.

${ }^{6}$ Russo 2004, 101.
} 
fers, but also in subsequent epochs, all the way to the folk traditions of the XIX and the beginning of the XX century.

Most of the mentioned researchers allow the possibility that Odysseus' shooting did not involve ordinary axes with a single blade, but double axes i.e. labryses. Taking this into account, as well as the apostrophized sexual-marital aspects of the mentioned act, of crucial importance in the revelation of its meaning will be to substantiate the female aspects of these objects.

\section{The axe i.e. labrys as a woman and goddess}

The relations between the labrys and the woman are a very important and complex topic that has been the subject of study by numerous researchers. We have also given great attention to it in our previous publications, which is why on this occasion, referring to these studies, we will present only our summarized observations. ${ }^{8}$

One of the strongest facts that confirm this relation is the pictorial representations of female figures accompanied by a labrys. Such representations are especially common in the Bronze Age cultures of Crete and the wider Aegean region, which can be classified into three basic iconographic types. In the first one, the figure holds one or two labryses in her hands, and is interpreted as a goddess or priestess, with the axe or pair of axes being associated with her authority over life and death (Pl.I: 1, 2, 5, 7, 8, 10), in some cases alternated with a poppy seed capsule and fruit of another plant (Pl.I: 6). In the second type, represented over her head is an assembly of symmetrically curved segments (so-called "snake frame") with a centrally placed double axe fastened on a handle (Pl.I: 3, 4). Both groups are most commonly found on seals, with the figure in the second type often accompanied by a pair of griffins or lions. The third type is represented by one of the Boeotian figurines from the Geometric period (the so-called "bell idols") on whose right side is a painted double axe (P1.I: 9). In another such specimen, a similar motif is found on the front part of the skirt (the genital area) but without a handle, which makes it uncertain whether it is really a labrys (P1.II: 9). It is thought that in the mentioned representations the labrys is not just an attribute, but also an epiphany of the goddess. ${ }^{9}$ In the ancient period, the character of such representations had changed. Various female figures appear with a labrys in their hands, and based on the accompanying inscriptions and comparisons, we can define their theistic character, and even the name of the depicted character. Numerous such depictions are present on the coins

${ }^{7}$ Our first observations on this topic were presented within the frames of our study of the Late Bronze and Iron Age objects in the shape of a labrys from the territory of Macedonia (Чаусидис 2017, Chapter 6).

${ }^{8}$ In detail on this topic, with presented bibliography: Чаусидис 2017, 687-692, 766-768.

9 Чаусидис 2017, 687-690. 
Pl. I
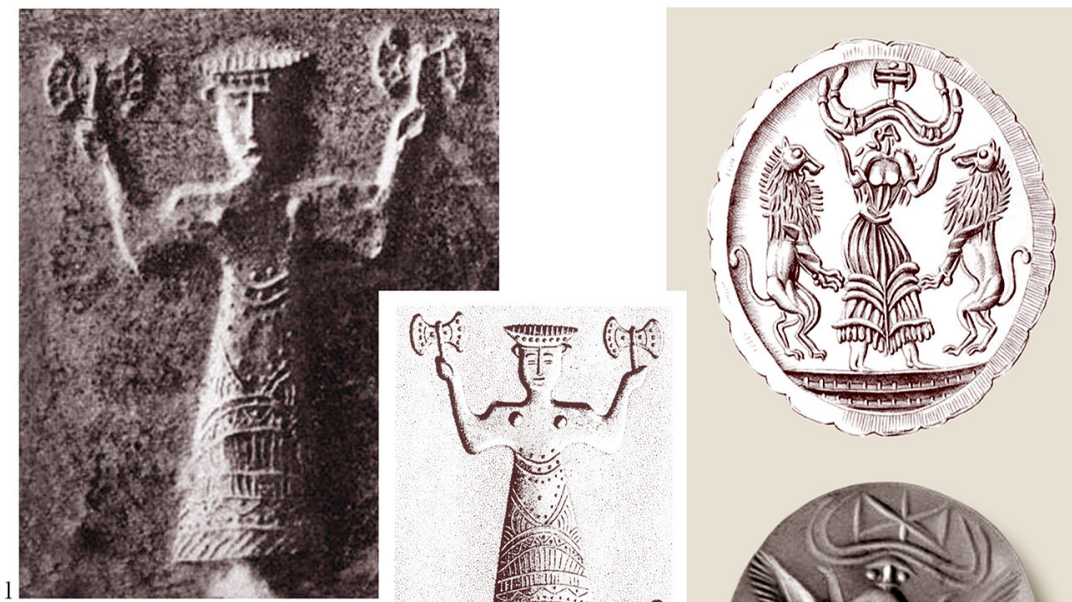

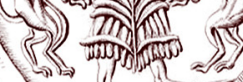
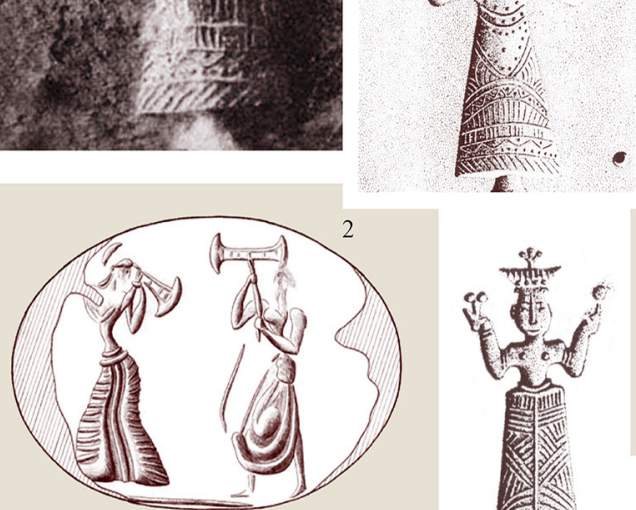

1.
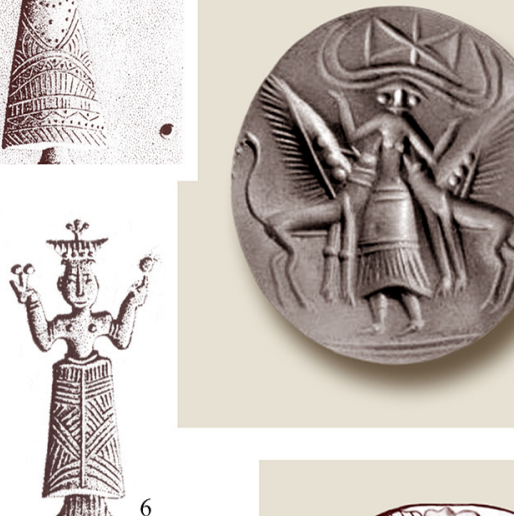

5

min:
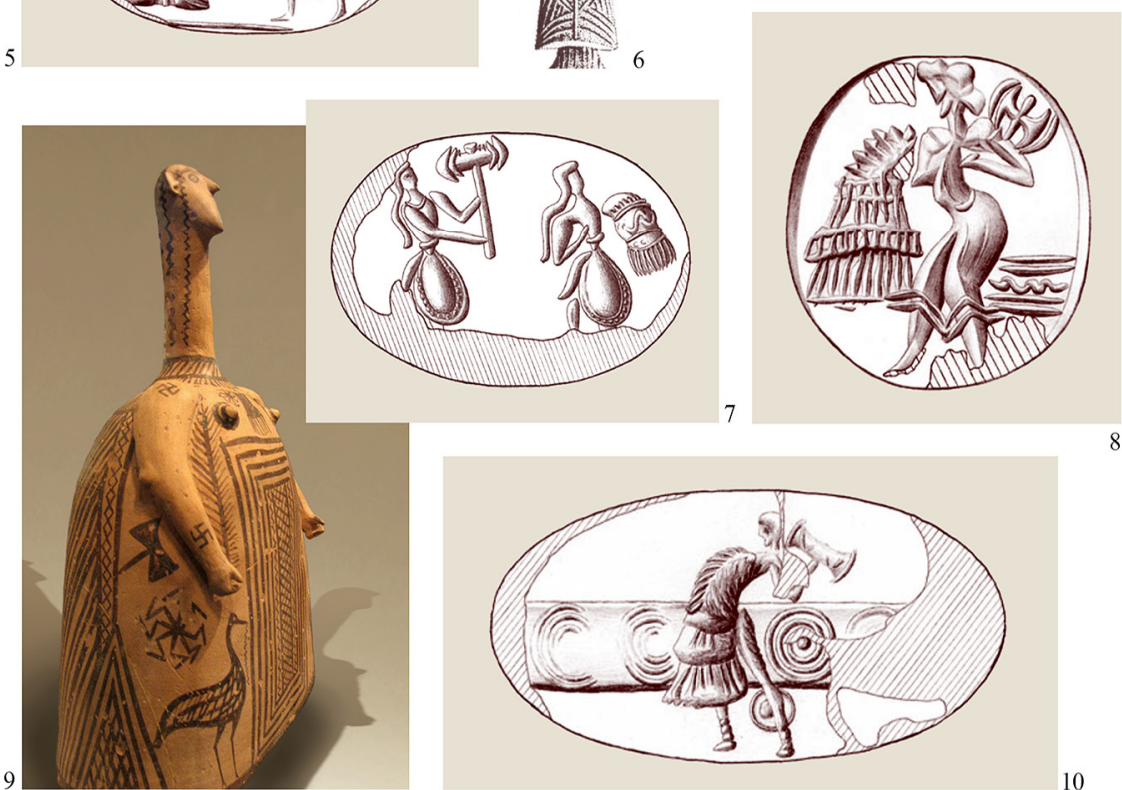

7

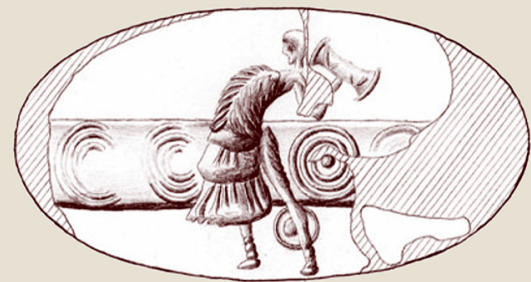


of the cities of Asia Minor (even up to the Roman period) where the labrys is combines with the figure of the local goddesses such as Ma, Cybele, Athena and others (Pl.II: 1-3). In the Classical period, depicted with a labrys in their hands are Thracian women, the Amazons, Clytemnestra and Cassandra, while the use of this tool receives a certain sacrificial significance (P1.II: 5,6$).{ }^{10}$

One such example originates from the territory of RN Macedonia. It is a bronze relief plaque (dimensions $12 \times 7 \mathrm{~cm}$ ) discovered as an incidental find in Pretor near Resen, which depicts a goddess standing in front of a temple (naiskos), with a radiant crown on her head and accompanied by a pair of dogs or wolves (Pl.III: 9). It is especially important for us that, in addition to the rest of her military equipment, in her right hand she holds a double axe with a pair of rounded blades, fastened on a short handle. According to N. Proeva, the plaque originates from the III century AD and depicts the goddess Ma i.e. Ma of Cappadocia. She is a goddess from Asia Minor whose character and cult were probably formed on the basis of the older Hittite goddesses (Hebat or the "Sun goddess of Arinna"). She was venerated in two cities with the same name - Comana in the region of Pontus and Comana in Cappadocia. By the ancient Hellenes, Ma was equated with Athena, Enyo and other goddesses, while in the I century BC she was also accepted by the Romans, equated i.e. syncretized with the Italic goddess Bellona (as Ma-Bellona). Apart from the mentioned find, her cult in Macedonia is confirmed by 14 inscriptions (all from the III century $\mathrm{AD}$, discovered in Edessa, Greek part of Macedonia), which is much more than all inscriptions found in the suggested native areas of this cult. It is thought that the dispersion of the cult of this goddess was due to the expeditions of Alexander the Great in Asia Minor, but also to the existence in Macedonia of an indigenous goddess with similar characteristics, functions and name. ${ }^{11}$ The labrys, the main element for which we refer to this find, is mentioned as one of the props used in the ecstatic rites in the temple of Ma-Bellona in Ostia (Italy), during which her priests, falling into a trance, self-harmed with this weapon. But, despite this, the double axe does not appear as a mandatory attribute in the pictorial representations of the goddess. In addition to the example from Pretor, on this occasion we can also present the depiction from a vessel discovered as a grave good in ancient Trier (Germany), which shows a female bust with a labrys on her shoulder that is identified as Bellona (P1.III: 10). Conditionally, some coins of Comana Pontica can also be taken into consideration here, on which the goddess $\mathrm{Ma}$ is combined with a shield and a club (probably as an alternation of the labrys - also a striking weapon). ${ }^{12}$

10 Чаусидис 2017, 690-692.

11 Proeva 1983; Проева 2014, 91-97; Stefanidou 2008; Hatzopoulos 1987, 404, 405; Чаусидис $2017,768$.

12 Proeva 1983, 168, 171, Fig. 5. 
P1. II
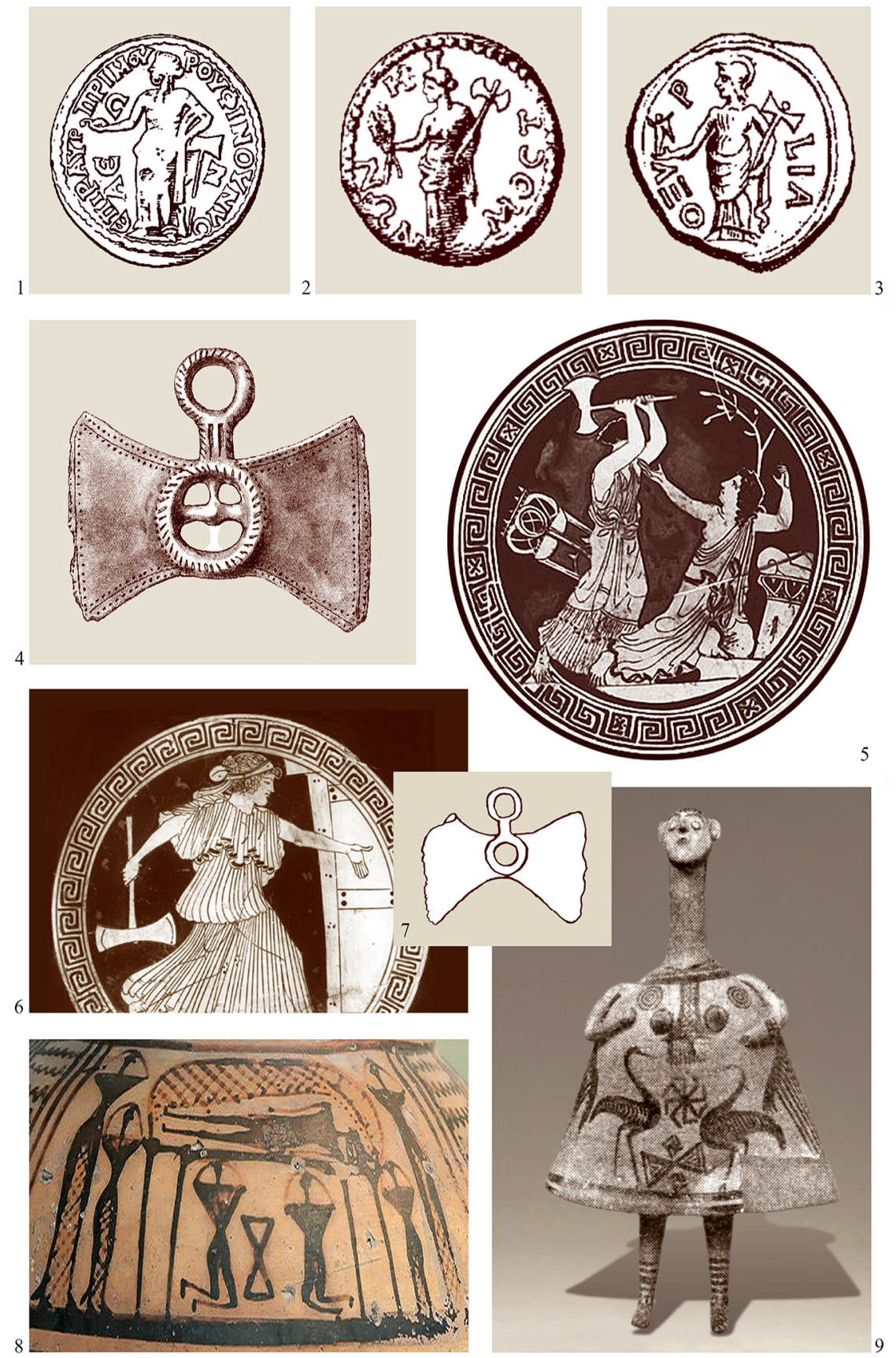
Although in the mentioned find from Pretor the labrys cannot be considered as a local Macedonian specificity of this goddess, but within the context of the other data presented here, we can treat it as a possible local affinity towards this symbol i.e. affinity for its combination with female mythical characters. The local predisposition towards this goddess may also lie behind the altar of Bellona found in the Roman town of Scupi (Zlokukjani, Skopje), this time perhaps as a result of the influence of Roman cults and the affinity of the local population towards the suggested traditions. ${ }^{13}$

There are indications that on the territory of Macedonia the symbolic relation between the woman and the axe also continued to be maintained within Christianity. There are medieval frescoes and icons depicting a standing figure of St. Marina that strikes the devil with a hammer, axe or similar tool (P1.III: 8; Pl.IV: 11). The oldest such depiction has been identified on the island of Corfu originating from the $\mathrm{XI}$ century $\mathrm{AD}$, while Macedonia, alongside Epirus and Albania, is one of the main core regions of such representations and the cult of the mentioned saint. The iconographic paradigms of this representation can be traced back to antiquity (P1.III: 11), while her pre-Christian layers and cosmological dimension are reflected in the mythical character of Fiery Mary. In Slavic and Balkan folklore, standing behind her is some archaic patron saint of lightning and counterpart of the Thunderer-God, represented by St. Elijah. In her western variant as St. Margaret, these aspects are represented through the struggle of this saint with the dragon (without the mentioned tool) as an equivalent of the devil and a zoomorphic personalization of the chthonic regions. ${ }^{14}$

The double axe is placed in relation to the human figure also through their direct equation. In fact, these are geometric images of the labrys (so-called "hourglass") in the form of two triangles placed on top of each other and joined with their vertex points, which this time also show greater resemblance to the figure of a woman (Pl.IV). Thereby, one triangle is identified with the upper half of the torso (the chest and shoulders), while the other - with the lower half (hips and legs covered with a skirt), where the narrow junction of the two triangles acquires the meaning of the thin waist, especially characteristic of the female silhouette. Although these motifs often retain their complete aniconicity (Pl.IV: 9), in numerous examples their anthropomorphic character is suggested by the presence of some strongly reduced elements (head, breasts, arms, legs) (Pl.IV: 3-8, 10, concave variants: 2). ${ }^{15}$

\footnotetext{
${ }^{13}$ For the find from Scupi: Драгојевиќ-Јосифовска 1981.

14 Чаусидис 2017, 768-771, Ѓ 47.

15 Чаусидис 2017, 684-686.
} 
P1. III
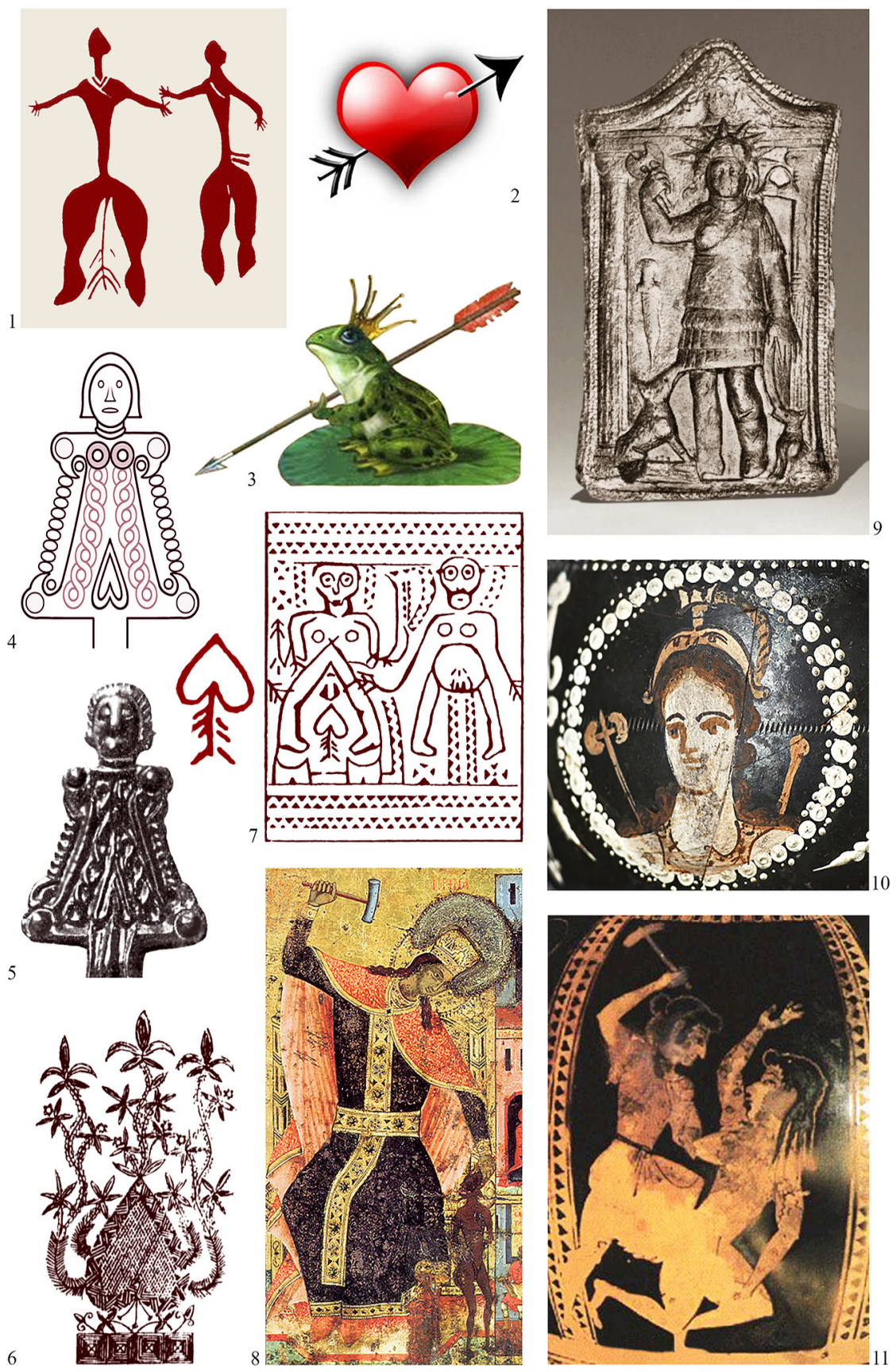


\section{The axe i.e. labrys as a vulva and uterus}

Multiple elements indicate that the double axe was not placed in a symbolic relation only with the woman as a comprehensive entity and figure, but also separately with her reproductive organs. In this sense, one should note the opinion of $\mathrm{M}$. Gimbutas according to which the mentioned sign of the labrys i.e. "hourglass" originated many millennia before the appearance of the real double axe as an object, dating back to the Paleolithic and Early Neolithic when it functioned as a symbol of the vulva represented in the form of a triangle. ${ }^{16}$ Even more specific is D. O. Cameron's proposal, which seeks the genesis and symbolic basis of the labrys in the act of giving birth to a female child when at one point the tip of the girl's pubis, touching the tip of the mother's pubis, forms the same symbol (compare with Pl.V: scheme 5 ) ${ }^{17}$ Summarizing the views of several previous researchers, it can be concluded that indeed, in certain cases, the creators, users and observers of the labrys and its pictorial depictions, consciously or unconsciously recognized in it a set of two pubes i.e. two vulvae oriented opposite to each other. In our previous studies we have suggested three possible meanings of such a grouping, which do not have to be mutually exclusive.

According to the first (already pointed out) meaning, on a symbolic level they would denote the Mother Goddess at the moment when she gives birth to her daughter who, inheriting her reproductive functions, will extend through time the duration of fertility and life according to the matronal i.e. the matrilineal concept. According to the second hypothesis, the two triangles would encode the complementary aspects of the Mother Goddess, one of which would represent the vulva as the creator of life and other goods. The other would denote the "anti-vulva", understood as a devouring mouth (vagina dentata) i.e. the factor of death which, in the end, destroys everything that she had previously given birth to by returning it within herself as a condition for new creation (Pl.V: 5; Pl.IV: 1). ${ }^{18}$ For example, this interpretation provides a possible answer to the presence of such a motif under the catafalque on a Geometric vase, most likely as a symbol signifying the death of the deceased, but also the impending rebirth that awaits him (Pl.II: 8). Within the third meaning, the two joined triangles are interpreted as a combination of the male and female principle, whereby the upper one, with its vertex point facing down, retains the meaning of the woman's pubis and the genitals placed within it. The lower triangle pointed upwards in this assembly would be featured as a sign of erect male genitalia (Pl.V: 6). In this context, the mutual touching and overlapping of the two triangles and their transformation into a hexagram

${ }^{16}$ Gimbutas 2001, 242, 243.

${ }^{17}$ D. O. Cameron, Symbols of birth and of death in the Neolithic era. KenyonDeane, 1981, 12 (according to: Hoti 1993, 45).

18 Чаусидис 2017, 717, 719. 
P1. IV
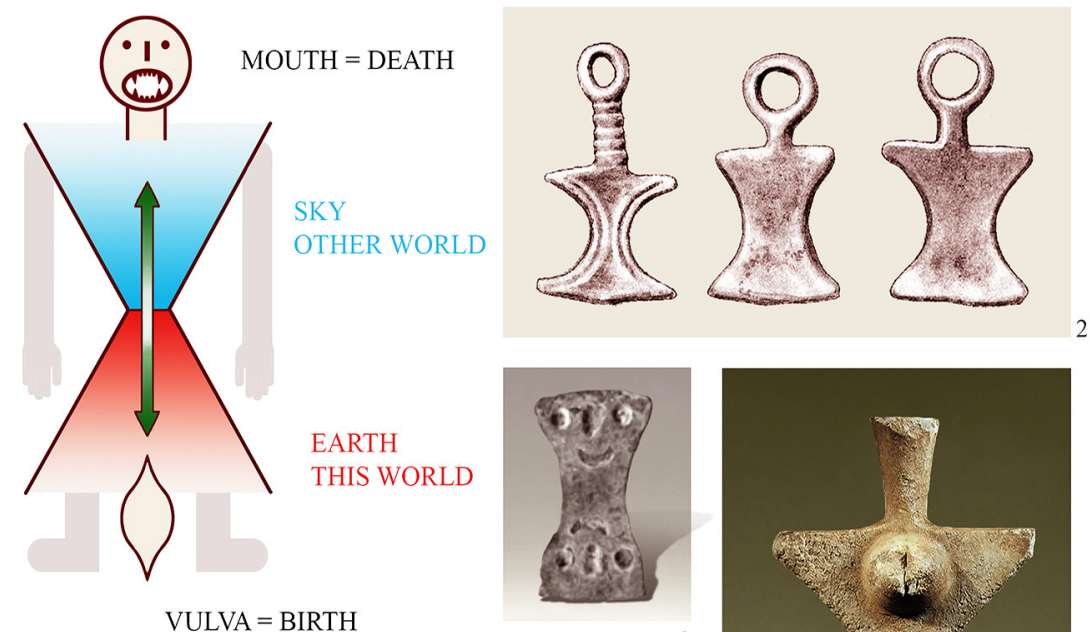

$V T V A=B I R T H$
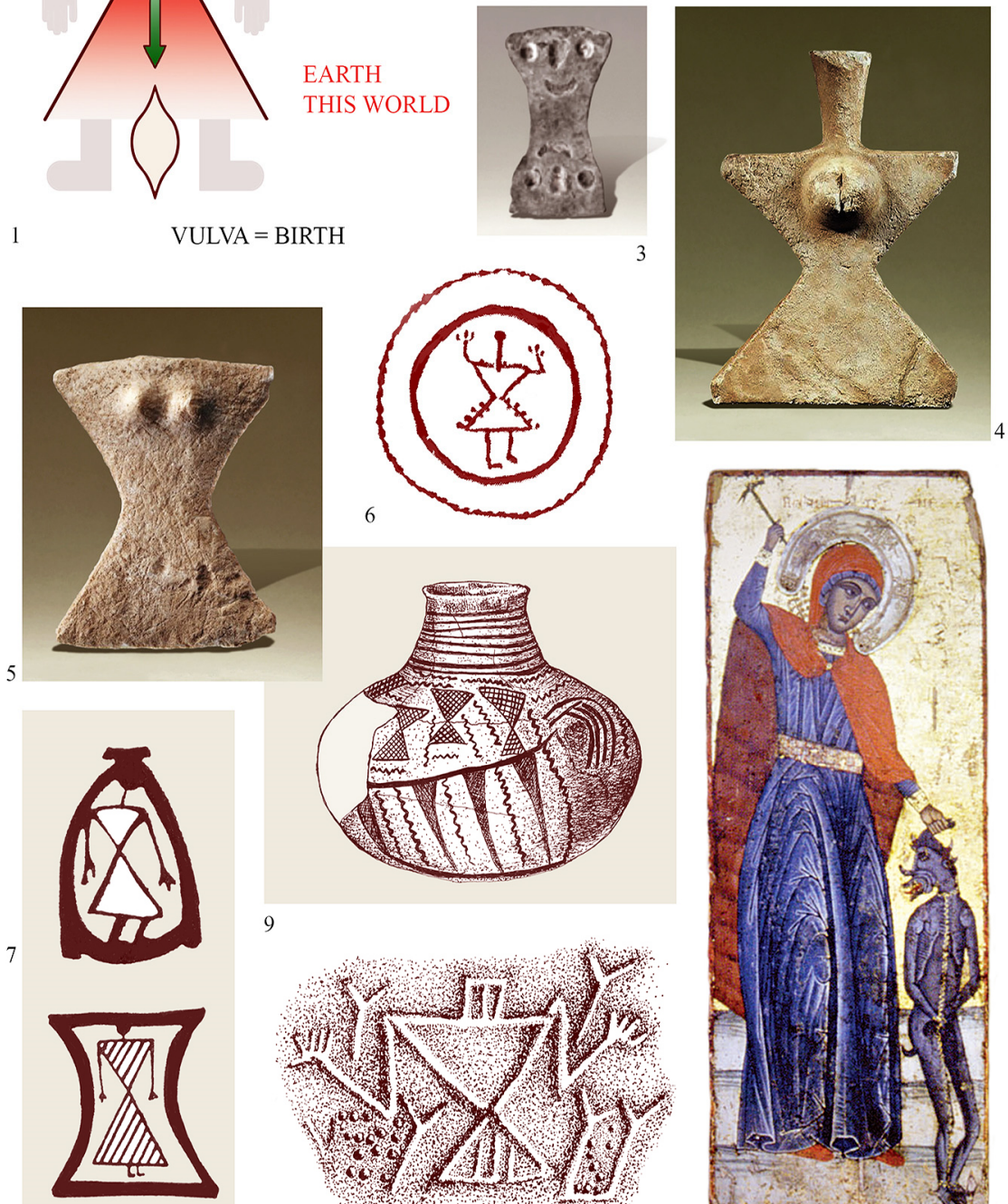

9
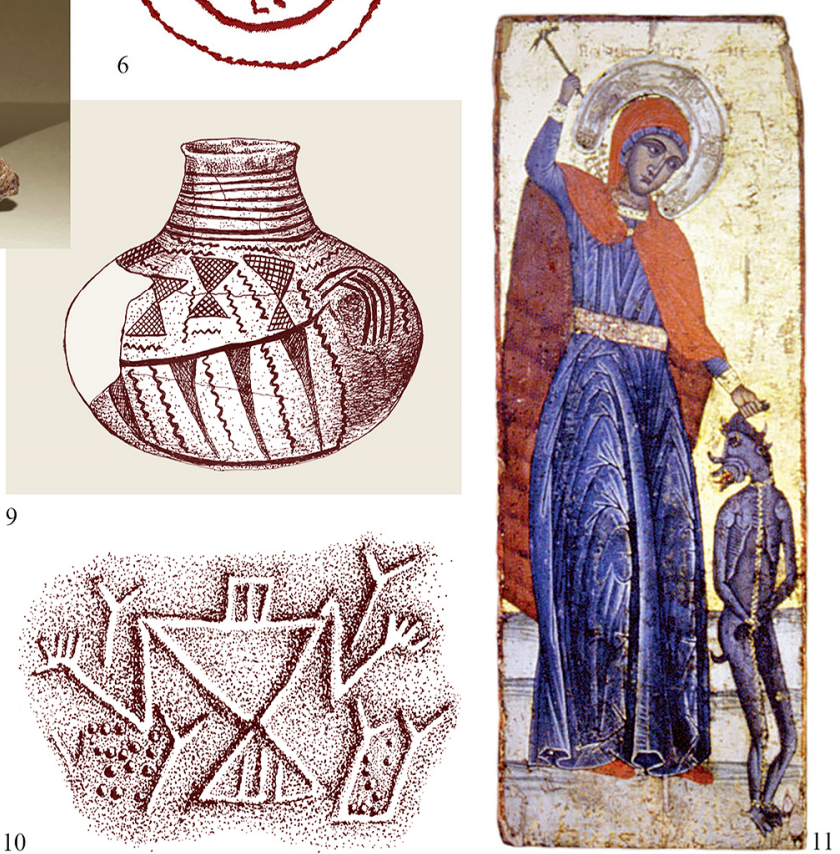
acquires the meaning of a union of the two principles (and the corresponding deities they represent) understood as their coitus and as hierogamy (P1.V: 6). ${ }^{19}$

\section{The opening for the axe handle as a vulva and uterus}

The reasons for the identification between the axe and the vulva (from today's perspective very unusual and with unclear motivation) cannot be sought only in the triangular shape of the pubis and the same shape of the tool's blade. It seems unbelievable that such a strong symbolic connection is based only on the random coincidence between the appearance i.e. the form of two things that are so different and even complementary in their essence: vulva $=$ soft, round, hollow, warm and creative, versus the axe = hard, sharp, full, cold and destructive. An answer to this question can be sought in the later prehistoric times, when first the stone and then the metal axe would get an opening for fastening the handle (Pl.VI: 1 - 4). Precisely this opening will complement the suggested relation with the key component which, besides the triangular shape, will make the axe even closer to the female genitalia. Thereby, this closeness will be based not only on the opening as such, but also on two other components with allusion to the coitus, namely the entry of the handle (= phallus) in the opening of the axe and the technology of piercing such opening (= coitus) ${ }^{20}$

The proposed identifications can be argued with a few examples of prehistoric stone axes in which they are also manifested on a visual level. The most explicit of such examples is the stone axe from Korovci near Murska Sobota (Slovenia) dated to the Copper Age (Pl.VI: 1). ${ }^{21}$ It is specific in that on one of its sides (front or back) is a depiction of an open vulva in relief, in the center of which was perforated the circular opening intended for the fastening of a handle. It is almost certain that during the manufacturing of the axe the vulva was depicted in its entirety, but with the constant sharpening of the blade, the lower part wore out. The motives for the existence of such a depiction can be understood if we take into account the technology of drilling holes in prehistoric stone tools. It is an extremely slow and laborious work that could take several dozen days to make a single opening. It was performed by placing a drilling tool (flint blade or tube filled with sand from a hard i.e. abrasive mineral) above the place designated for piercing, and then gradually wearing out the intended part of the tool with rotational movements (Pl.VI: 5). ${ }^{22}$ Having in mind the

\footnotetext{
19 Чаусидис 2017, 715, 753, 981, Ѓ29; Чаусидис 2015, 86-88, Т.XIII.

20 The following observations, accompanied by additional argumentation, are also presented in our previous publications: Чаусидис 2005b, 148, 149; Чаусидис 2008, 24, 25; Чаусидис 2017, 692-695.

${ }^{21}$ Stalna 1997, 13; for this conception in a different context: Чаусидис 2005b, 148, 149; Чаусидис 2008, 24, 25.

22 For the drilling techniques: Solenhofen 2020; Малинова \& Малин 1988, 142 ff.
} 
mechanism for performing this procedure, we believe that the depiction of a vulva on this particular axe emerged as a result of associations between the process of its drilling and the coitus, based on the components "piercing" with "elongated object", followed by "friction". ${ }^{23}$

Today it is difficult to reveal the authentic context of this depiction i.e. whether it is present on the axe as the result of magic or ritual, personal (and slightly perverted) association or joke. Regardless of the context, one can think that during the long and monotonous activity, the depiction of the vulva gave the maker of this axe additional motivation, energy and meaning, drawing willpower from his, probably, not entirely conscious instinctual spheres. However, several other examples support the claim that this is not an exception, but a more widespread phenomenon. Considering that the rhombus is the most common symbolic equivalent of the vulva, ${ }^{24}$ we can add to the previous example the bone axe socket from Maliq (Albania), also from the Copper Age, on which a rhombus is carved around the handle opening (Pl.VI: 2). Analogous rhombic motifs, supplemented with various other details, can be also seen on the stone axes-hammers from the Middle Bronze Age within the Catacomb culture and the Ingul culture from the North Black Sea region (Pl.VI: 3, 4) ${ }^{25}$ The motif of a stylized vulva placed between the two blades can be implicitly recognized even outside of its function as an opening for the labrys handle. Such is the case with the Bronze Age labrys-razors which, regardless of the fact that they were not fastened on a handle, almost always have a circular opening between the two blades, in some cases also supplemented with a cross-shaped element (P1.II: 4, 7; P1.VI: 6, 7). ${ }^{26}$

Such a meaning can be also confirmed through the contemporary traditions of Slavic and Balkan folklore, with a preserved living context, which also point to the diachronic i.e. transchronological endurance of this phenomenon. Namely, several ritual-magical procedures from these ethno-cultural areas included the practice of pulling i.e. pouring certain substances through the opening of various tools intended for fastening a handle (axe, adze, hammer). Usually it was a seed intended for sowing, or water, milk, or some other liquid that was then

${ }^{23}$ The last of the components (friction), in some South Slavic languages has a synonym (Macedonian: абе (abe), абење (abenje); Serbian and Croatian: хабане (habanje) whose root, it seems, is also incorporated into the most frequent Slavic words denoting coitus (Macedonian: ебе (ebe), ебење (ebenje); Serbian and Croatian: јебе (jebe), jeбarbe (jebanje). On the previous etymological interpretations of the lexemes: Gluhak 1993, 158 (habati, habam, whereby especially indicative are the relations with the meanings *xobotz; gurati, udarati, *skabh - „strugati, rezati, dupsti (oštrim oruđem)”; lat. Scabo „grebem, češem”, scabies - „hrapavost, svrab”), 293 (jebati, jebe); Skok 1974, 765 (jebati), 645, 646 (habati).

${ }^{24}$ On the rhombus as a schematized vulva: Чаусидис 2005a, 93-100 ff.

${ }^{25}$ Shqip. Arkeologike 1971, 13; Василенко et al 2007, 91, 92 - Рис. 12.

${ }^{26}$ Other examples and arguments: Чаусидис 2017, 693, Ѓ15: 2; Ѓ19: 7, 8. 
P1. V

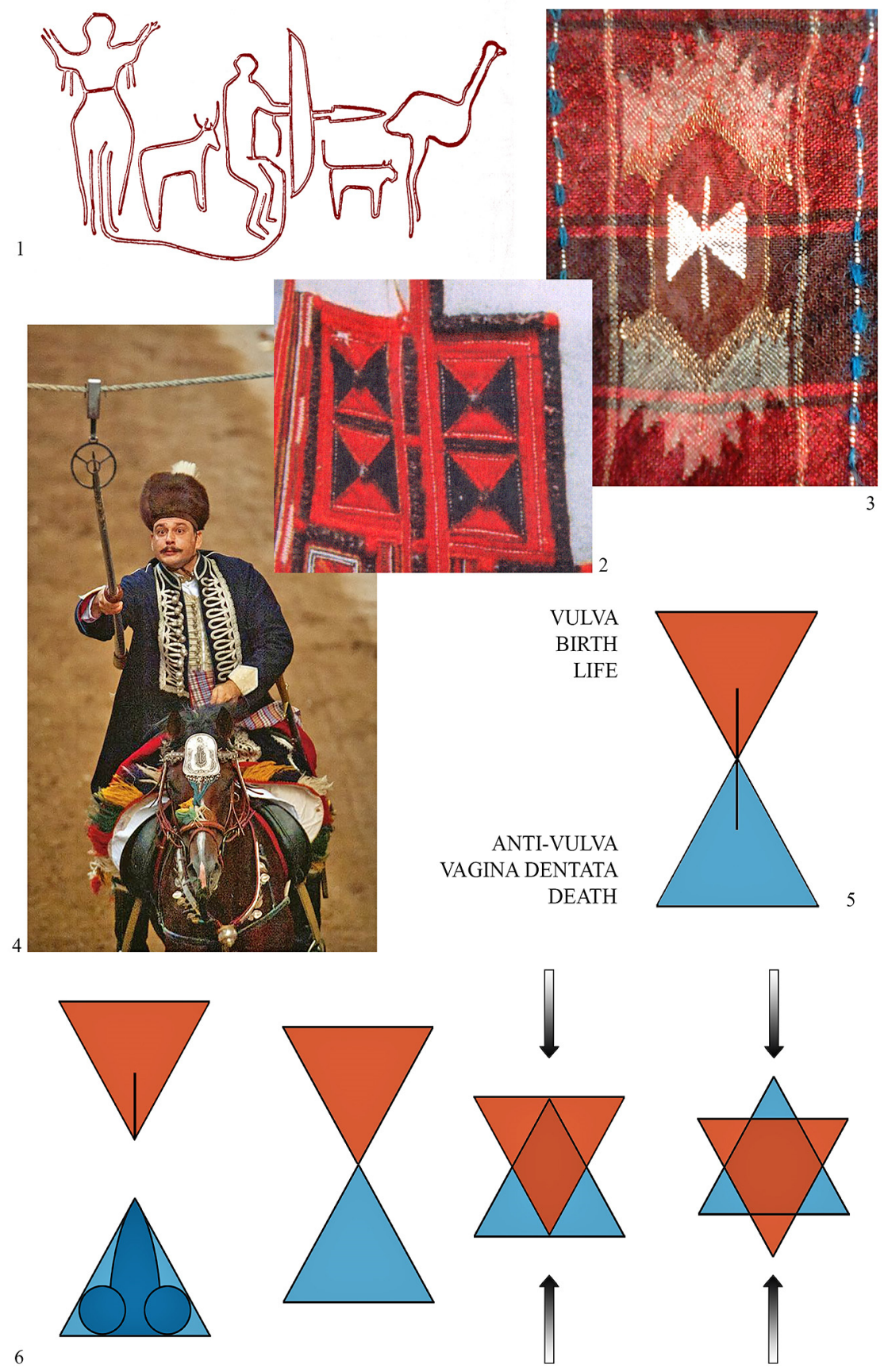


used for healing. ${ }^{27}$ Since the above axes are made out of stone, also interesting are the variants of such procedures in which the healing substance is poured through a hollow stone i.e. stone with an opening or through the opening of a stone axe. ${ }^{28}$ Interesting within this context are also the myths (recorded, for example, among the Dogon people in Africa) in which the basic agricultural crops (rice, peas and other local species) were brought to earth by the first mythical blacksmith who gets or steals their seeds from the supreme god Amma, and transfers them from heaven to earth by putting them in the opening of his hammer. ${ }^{29}$ In this case the opening of the hammer has the meaning of a channel i.e. gateway between "this" and the "otherworld", which is a function also inherent to the female genitalia. The opening of the axe (as well as the opening of the hoe and the eye of the needle) has the same meaning in the verses of the "Kalevala", according to which the "evil flame" can be expelled from this world through it. ${ }^{30}$

Based on the presented material and the proposed interpretations, it can be concluded that in archaic cultures the opening of the axe (and other similar tools) carried the meaning of vulva and uterus, which gave the mentioned procedures the character of a new beginning, mythical rebirth, improvement and sanctification, providing various positive properties to the substances pulled or poured through it (fertility to the seeds and healing properties to the liquids).

We think that the presented examples and analyzes give serious arguments in support of the hypothesis that the axes through which Odysseus shot his bow and arrow did not represent the woman or a goddess only in some abstract i.e. aniconic, but also in a very specific context, suggesting to their reproductive organs, whereby the opening in these axes signified the opening and the internal cavity of those organs i.e. the vaginal opening, the vaginal cavity and the insides of the uterus. However, the arguments presented so far do not answer the question about the multiplication of the axes in the specific number of twelve, for which we give additional arguments presented in the next chapter.

\section{Multiplication of the axe i.e. labrys}

If we take into account that in archaic cultures the decimal numeral system was often alternated with the duodecimal (dozenal) numeral system, it can be assumed that multiplying the axes to the given number

${ }^{27}$ Examples: Колева 1967, 181, 182; Чеха 2012, 289; for these and the following examples: Чаусидис 2017, 693, 695.

${ }_{28}^{2}$ Цивьян 1999, 312; Gimbutas 1973, 477 (by the term stone axe the author probably means the prehistoric stone axes that were accidentally found by the villagers).

${ }^{29}$ Elijade 1983, 99, 100; Иорданский 1981, 67, 68, 84 (also referring to the equation between the opening of the tool and the vulva is the local proverb "the power of the hoe is in the handle", in which the handle acquires the meaning of a phallus).

${ }^{30}$ (Kalevala. Rune 47). 
P1. VI

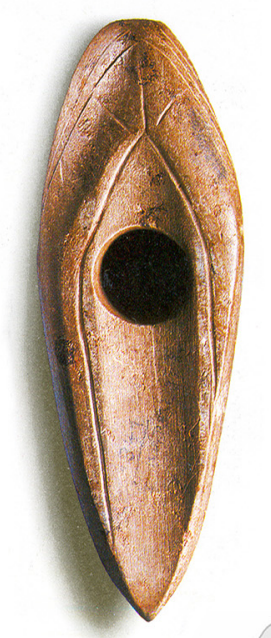

1
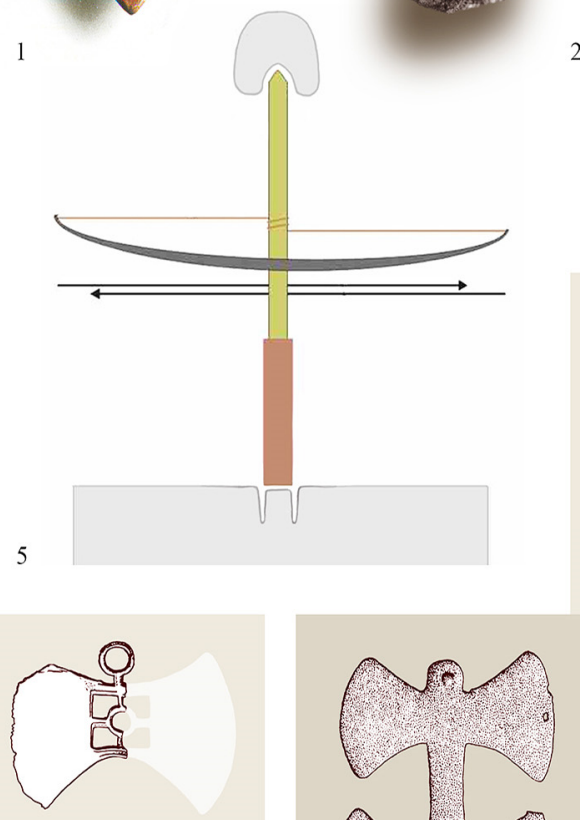

6

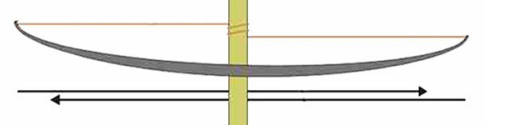

2
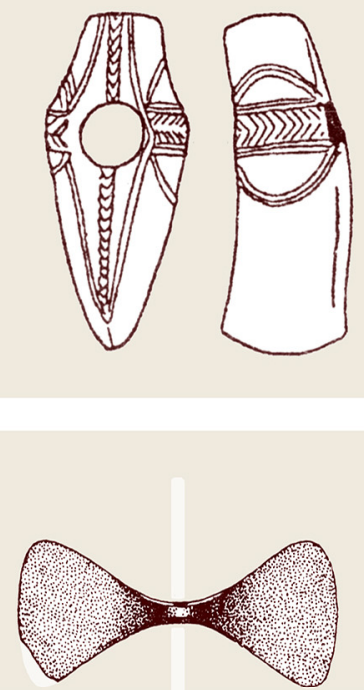

4

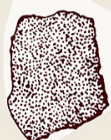

7
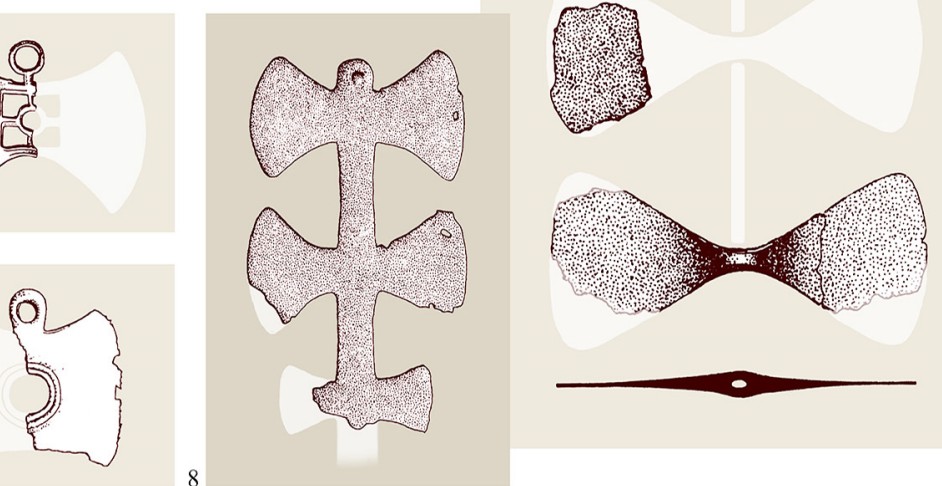
simply meant "a lot", or "infinitely", represented by some rounded up and/or sacralized number. However, one should also not avoid the possible time-related i.e. calendric significance of this number or more specifically - its relations with the annual cycle represented by the 12 months. In this context, if we accept that the act of shooting through the axes indicates coitus, then the passing of the arrow through the 12 axes could indicate the repetition of that act every month throughout the year and/or its continual duration during all of the months that make up the annual cycle i.e. continuously i.e. all of the time. Such a meaning could refer to the microcosmic level, in relation to the archer's wife (or the several wives within his eventual polygamous marriage), but also to the macrocosmic level as his sexual act with some goddess (understood as hierogamy).

As an important argument in support of the proposed time-related i.e. calendric aspects of this act, we can also present some archaeological finds discovered on the territory of Macedonia, which based on their chronological and cultural affiliation could indicate some more direct relations with the Aegean cultures that participated in the formation of the contents of the Odyssey.

We are referring to a type of belt sets composed of strung double axes discovered at the necropolis "Dimov Grob" near Ulanci (Gradsko, RN Macedonia), which date back to the XIII-XII century BC. They were found in situ in two graves, placed at the waists of deceased, both of them of female sex (P1.VII: 1-6). In both cases, the grave structures are in the form of a cist, part of a flat necropolis, in which the deceased were laid sideways on their left side, in a half-contorted position. The careful and well-documented excavations have shown that these were sets consisting of a larger number of double axes cast in bronze, which were strung on some kind of cord in combination with two or four beads of glass paste and several of bronze. The set from grave no. 54 is composed of 14 double axes (P1.VII: 2 - 4), while the one from grave number 80 consists of 26 axes (Pl.VII: 1, 5, 6). It is very important to accentuate that in both sets the gradual increase in size of the axes is clearly emphasized, so that the largest ones, placed at one end, are twice as big as those at the opposite end. The labryses themselves were produced in a simple manner, with a central perforation and without any additional finishing of the surface. Their side edges are flat, while the contours of the blades are slightly rounded. ${ }^{31} \mathrm{~A}$ belt with remains of labryses was also discovered in grave no. 13 from the same necropolis, for which we are not acquainted with any other details or illustrations. ${ }^{32}$

Z. Videski thinks that, in addition to the obvious decorative function, these sets also had a cult purpose as elements of certain rituals. At the same time, however, he prefers the hypotheses according to

\footnotetext{
${ }^{31}$ Videski 2007; Митревски 1997, 316, 317.

32 Videski 2007, 317 - footnote 2.
} 
Pl. VII

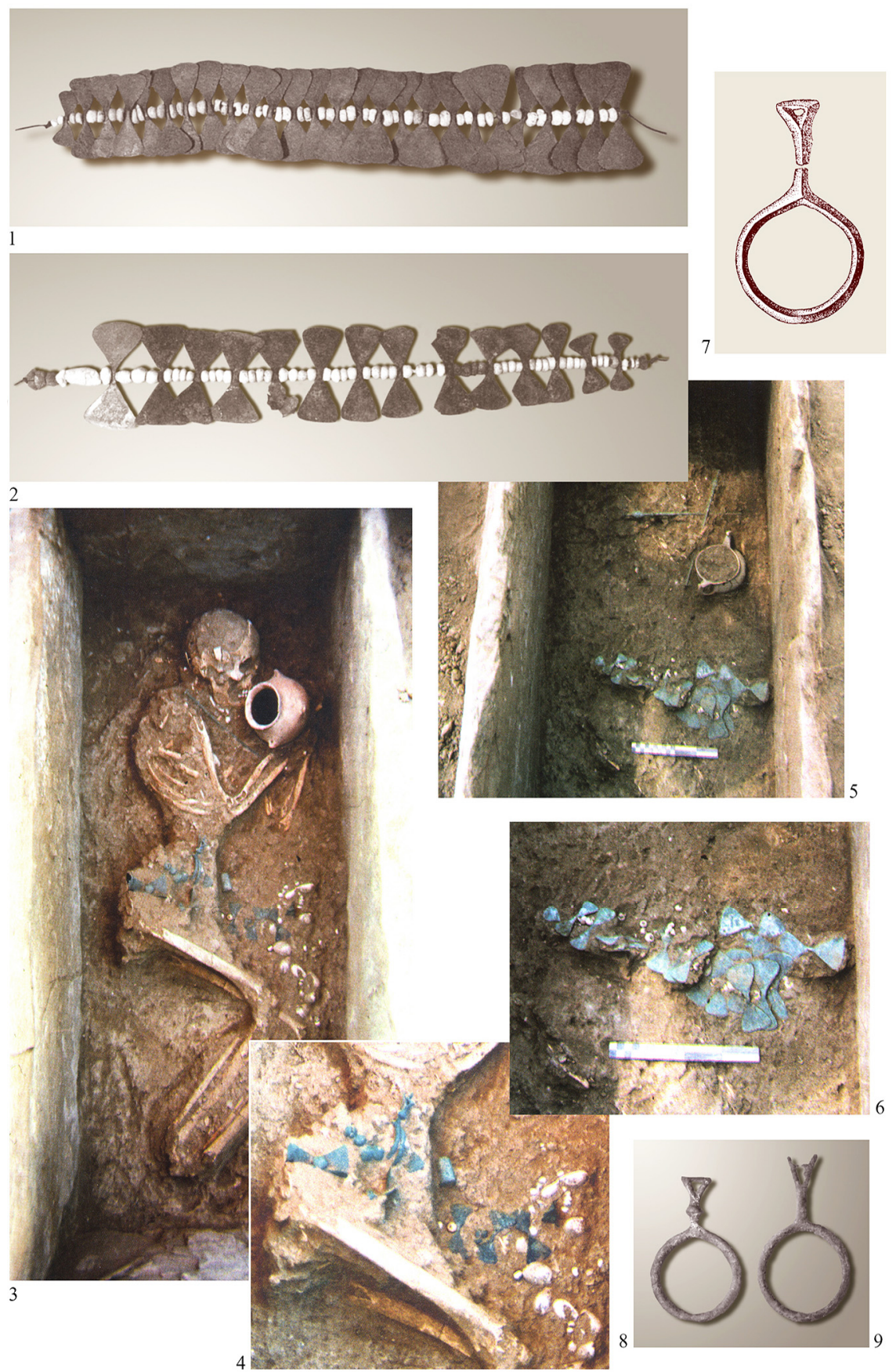


which they are supposed to be some kind of religious equipment or religious elements of clothing ("religious garments or their accessories"). He relates them to the Aegean Bronze Age cultures, and, based on the finds of the said necropolis, believes that they did not influence this part of the Balkans just at the level of the material, but also of the spiritual culture. The author points to the possible older and continual influences from the mentioned region, which, during their further development, would participate in the formation of the basis for the later beliefs of the Paeonians in the Iron Age. Specifically, he treats these objects as symbols of the goddess of the house i.e. the family ("household goddess"), in support of which he takes their presence in the female graves of the mentioned necropolis. His interpretation for such a cultic and specifically female character connected to fertility was also indicated by the presence of the sea snail pendant in grave no. 54, the round bronze pendants (P1.VII: 8, 9) and the pairs of long bronze needles crossed at the chest. Based on these facts, he also proposes an assumption about the status of the deceased as members of the higher ranks of society, which were specialized in the spheres of religion, probably with the status of religious leaders i.e. priestesses. ${ }^{33}$

If in the context of these finds we also view the three labryses from Tremnik (Negotino, RN Macedonia) (P1.VI: 9), it becomes just as likely that they would not have to be part of a set with only three double axes, carried on the neck or chest (as hitherto thought), but as a arrangement of several such elements (lost during their accidental discovery) which, strung on a thread, stood at the waist. Besides the shape of the double axes, very similar to those from Ulanci (compare Pl.VI: 9 with Pl.VII: 1,2), this is also indicated by the presence of the same round pendants made of bronze in both collective findings (Pl.VII: 7 - from Tremnik and 8, 9 - from grave 54 in Ulanci).

Very indicative concerning the Late Bronze Age belt sets found at the necropolis near Ulanci is the numerical representation of the double axes i.e. their blades: the set from grave no. 54 consists of 14 (Pl.VII: 2), while the other one from grave number 80 has 26 labryses (Pl.VII: 1). These numbers do not attract some special attention until we count their blades. Namely, the 14 labryses from the first set present us with 28 blades, which correspond to the number of days in a lunar month. The second set, with its 26 labryses, offers 52 blades, which corresponds to the number of weeks in a calendar year. These comparisons indicate the coding of certain calendric aspects that fit well with the shape of the sets arranged in the form of a thread closed

${ }^{33}$ Videski 2007, 316, 317, 319; D. Mitrevski also connects the genesis of these objects with the Bronze Age cultures of the Aegean or more specifically of Crete (Mitrevski 2006, 89, 91; Mitrevski 2010, 17, 18); these conceptions are also accepted by A. Papazovska (А. Папазовска Санев 2015, 49, 50; Papazovska 2018, 123-126); for our observations on the ethnocultural affiliation of the necropolis see: Чаусидис 2017, 859$861,863,994-996$. 
as a circle (= cyclical time, month, year) on which the labryses $(=$ days, weeks) are strung. Given the female sex of the owners of this jewelry and its wearing at their waist i.e. hips, we consider justified the thought that in this case the meaning of the labryses and their numerical representation were focused on the functions of the reproductive organs located in this part of the female body. ${ }^{34}$

Within the frames of the stimulatory function, it could be understood as the presence of the divine fertilizing power of the labrys in the female genital area, every day of the month or every week of the year (perhaps due to the sustentation and proper timing of the menstrual cycles). Within the frames of the apotropaic function, it could be a matter of continuous protection of the reproductive organs of the woman and the child within them from diseases, negative magic and other unfavorable factors. In both cases, the numbers indicate the emphasizing of the lunar cycles, which is an additional argument in favor of the relations with the female fertility cycles (menstrual cycle, pregnancy) that are in correlation with the lunar cycles. The sets from Ulanci have a clear tendency of gradually increasing the dimensions of the axes starting from one end of the arrangement to the other (Pl.VII: 1, 2), which can also be sensed with the pendant from Tremnik (Pl.VI: 9), as well as with a triple labrys from Vergina (Greek part of Macedonia) (Pl.VI: 8). This can be interpreted as an intention to evoke the growing aspect of a category that was supposed to be symbolized by the set. Observed on a macrocosmic level, it can mean the growth of the day, the moon, the awakening and growth of vegetation, while on a microcosmic - the growth of the fetus in a woman's womb. ${ }^{35}$

We are not acquainted with any other examples of labryses that we could present as parallels to the mentioned numerical structures. As the closest (although not identical) analogy we point out the crypt under the sanctuary in Knossos on whose two square stone pillars were engraved 29 labryses $(=28+1$ ? $){ }^{36}$

The calendric aspects of these interpretations open the possibility of their connection with the topic of this article - the shooting of an arrow by Odysseus through the 12 axes, with the difference that in this case the annual cycle would not be coded through the 52 weeks, but through the 12 months of which it consists.

In Macedonia, the presence of multiplicated double axes in the area of the female reproductive organs can be followed up to contemporary folklore, through such motifs embroidered on women's clothing from the region of Kriva Palanka (RN Macedonia) (Pl.V: 2, 3). This is supported not only by the shape of the motif (compare to Pl.IV; Pl.VII), but also by its name 'sekirički' (literally meaning "small

\footnotetext{
34 Чаусидис 2017, 764, 765.

35 Чаусидис 2017, 764, 765; Чаусидис 2020, 42-44.

${ }^{36}$ Hoti 1993, 49.
} 
axes"). ${ }^{37}$ It is especially indicative that it was applied to the skutina (Pl.V: 3) - an element of clothing with a pronounced symbolic character that covers the woman's thighs, hips, genitals and abdomen, and to the kjurdia (Pl.V: 2) - an element that hangs over the back of the torso, buttocks and thighs. ${ }^{38}$ It is important to highlight that the "labryses" on these two elements of the folk costume, analogous to the sets of Ulanci (Pl.VII: 1, 2), form some kind of symbolic circle around the genital area of the woman.

\section{The arrow as a symbol of the male principle}

Deserving of some attention in our study is also the second element of the ceremony held at Odysseus' palace - the arrow which shot from his bow passes through the openings of 12 axes. The masculine aspects of this weapon, which are indicated by the results of the previous analyzes, are much more obvious and better explored. Therefore, we will dedicate less attention to them by presenting some global observations accompanied by appropriate literature and some of the most illustrative examples. ${ }^{39}$

The equating of weapons with the phallus has an archetypal character i.e. it runs through various cultures that are very far from each other both in a geographical and chronological sense. Thereby, this equation loses its explicitness inversely proportional to the degree of civilization of the given cultures, so that it is covered by the veil of metaphor and by shifting to the emotional or spiritual aspects of the erotic at the expense of the sexual ones. In ancient period, the most evident in this sense are certainly Eros and Amor as "gods of love", with the bow and arrow as their main attribute. Although they carry the function of initiators i.e. causers of the erotic relationship between man and woman, the indicated phallic aspects of their bow and arrow are not explicitly expressed, at least not in the usual works of classical ancient art and culture. If such a character were to be preserved for their weapon, the arrow should obviously be directed only towards female characters.

Much more transparent in this sense are the traditions of the more archaic cultures in which the suggested meanings of the arrow are much more explicit and are part of the living culture i.e. everyday life. It is a common custom among the peoples of the steppe regions of Asia for a boy to shoot an arrow from his bow (often lit) towards his chosen bride (that is, towards her yard, dwelling, or father) as a sign of his intention, whereby taking the arrow meant the acceptance

\footnotetext{
${ }^{37}$ Кличкова 1963, 3; Чаусидис 2017, 765.

${ }^{38} \mathrm{On}$ the apotropaic and other magical aspects of the skutina and women's clothing in general: Чаусидис 2009, 203-206; Чаусидис 2005a, 129, 130, 139-141.

${ }^{39}$ On our previous studies on the phallic aspects of the arrow within the frames of other stabbing tools: Чаусидис 2008, 8-13; Чаусидис 2005b, 138-144; Чаусидис 2015, 86.
} 
of the offer. Apart from real actions, this act is also frequently present in archaic myths, stories and epic works, often by replacing the woman with some other symbolic element. ${ }^{40}$ Also known are wedding rituals in which the veil is lifted from the bride's face with an arrow, which in our context, among other meanings, acquires the meaning of her symbolic defloration. ${ }^{41}$ In ancient mythology, this meaning is often non-transparent, due to the various new symbolic layers over the main action. $^{42}$

It is no coincidence that in fairy tales, the arrow of the prince ends up at the frog, which will later become his wife (P1.III: 3). This is due to the fact that in many cultures, the frog is a paradigmatic symbol of the female principle, a representative of earth and its fertility, and often a substitute for the female genitalia (vulva and uterus). ${ }^{43}$ In this context, it is interesting to note that in some South Slavic languages or some of their dialects, the word ' $z a b a$ ' (frog) is used as a metaphor, even as a synonym for female genitalia, or as a name for some technical elements that embody certain features and functions of the vulva, for example, 'žapka' and 'žabica' (literally meaning "froglet”) - a name for the socket in which the door shaft enters or for the opening through which some kind of belt is passed. ${ }^{44}$

In modern mass culture, the image of a heart pierced by an arrow is present up to this day as a symbol of love (P1.III: 2). An analysis on the meaning of the heart through various epochs and cultures shows that in this case also, it was primarily used as a symbol of the genital area of the female body (as seen from behind), and indirectly of the vulva and uterus. This is why in ancient and archaic cultures it was depicted with the top upside down, which further reduces the visual relations with the true heart whose real shape does not correspond to this image in any way (P1.III: 4 - 7). We believe that the key to this identification lies in the real relations between the appearance and characteristics of both elements. Namely, both the heart and the vulva are vital organs, on which human life is based. In the eyes of archaic people, both could be defined as hollow muscles that contain blood i.e. it passes through them (work of the heart, menstruation). This means that today's meaning of this image as a symbol of the spiritual i.e. emotional aspects of love (based on the notions of the heart as the seat of the spiritual and of emotions) are secondary, while behind it primarily stood a much more open, vulgar, material and biological aspect

40 On the arrow as a marital symbol: Венедиков 1987, 63-67; Анисимов 1959, 64, 65; in Bulgaria: Георгиева 1983, 67; Мороз 1989, 453, 454; on impregnation by wounding with an arrow: Matić 1979, 194.

${ }^{41}$ On the ritual (without the suggested interpretation): Зарубин 1925, 92, 93.

42 Indicative in this sense is the combination of the archer with one of the female deities, or with a representation of a tree (see: Станилов 1981; Савостина 1983).

43 Чаусидис 2008, 12; Чаусидис 2015, 86.

44 About this and generally on the female aspects of the frog: Чаусидис 1994, 176181; Чаусидис 2005a, 165-167; Чаусидис 2017, 841-845, 992. 
of the relationship between man and woman - coitus. This is most explicitly shown by a motif carved on a distaff from the area of Croatia (XIX century) where, besides the realistically depicted pair of a naked man and naked woman, there is a heart pierced by an arrow, but depicted in a way that much more explicitly alludes to coitus (P1.III: 7). An interesting parallel to this image (this time more explicit and without the symbolic mediation of the "heart") seems to be found on a prehistoric petroglyph from Gobustan in Azerbaijan (Pl.III: 1). In such a context, the phrase „od cpue nopod" ( "od srce porod” = "birth from the heart"), common in Macedonian and in the wider traditions of South Slavic folk culture, which literally denotes birth from one's own womb i.e. uterus, takes on a new pragmatic meaning. There are also known examples of early medieval jewelry in which indicative of the relation "heart - vulva" is the positioning of a heart-shaped motif (oriented with the pointed part upwards), depicted in the genital area of a stylized female figure with accentuated breasts and limbs that end in the form of bird protomes (Pl.III: 4, 5). Also common are examples in which, from the pictorial depiction of such a rotated "heart" grow various phytomorphic motifs, referring to the symbolic relation heart vulva - womb of the earth from which plants actually grow (P1.III: 6). ${ }^{45}$

In the opening paragraphs we mentioned the parallels for the feat in the Odyssey presented by C. J. Russo, in which the shooting of an arrow through axes is alternated with shooting through other elements, such as: through a hoop, through a wheel opening or through the mouth of a wild boar. For each of the mentioned elements, one could present arguments that would indicate their feminine signification i.e. the symbolic relations with the female genitalia. Circular objects such as rings, bracelets, hoops and wheels are often combined and even equated with the human figure, and often more specifically with the female one, most commonly as the personification of a life cycle whose creator and maintainer is the woman, or of human destiny which in archaic cultures is usually under the control of female deities. ${ }^{46}$ The mouth of the boar acquires the suggested meaning on two premises. The first one is by the equation of the mouth with the vulva as the two most dominant openings in the body, located at its opposite ends. ${ }^{47}$ The second is based on the equation of the woman and the female genitalia with the sow, especially prevalent in ancient Mediterranean cultures. ${ }^{48}$

Another example from Macedonian folk tradition exceptionally illustratively reflects the equation of the phallus with the stabbing weapon. At the beginning of the last century, in the surroundings of

${ }^{45}$ In detail about all of this, with numerous examples: Чаусидис 2005a, 203-205: Чаусидис 2015, 76-78.

${ }^{46}$ Ефтимовски 2020; Чаусидис 2017, 643, 645.

47 On the relation mouth - vulva: Чаусидис 2013.

${ }^{48}$ On the relation sow - vulva: Чаусидис 2017, 832- 835. 
Gevgelija (RN Macedonia), it was considered an insult to the host, as well as humiliation and an attack on the honor of the female part of his family, if during a home celebration, one of the attending male guests pulled out a knife from his belt and stabbed it in the hearth of the house. Based on the concept presented here and the well-known relation hearth - vulva - uterus, clearly manifested through the cult of the ancient goddesses of the hearth (Hellenic Hestia and Roman Vesta), it can be concluded that in the described undesirable act, the knife carries the meaning of a phallus, while its stabbing in the hearth - of illicit coitus. $^{49}$

All key elements of this study are contained in a ceremony that to this day takes place on the Adriatic coast in Sinj (Croatia). It is called "Sinjska alka" (from alka = hoop), and consists of a competition in which men, galloping on a horse with a spear in their hand, have to impale a hoop hanging high above the ground that is made of two concentric rings connected by three bars (Pl.V: 4 compare with Pl.II: 4, 7; Pl.VI: 6, 7) ${ }^{50}$ As in the case of Odysseus's arrow shooting, this traditional ceremony focuses on the competition between men in their martial skills. However, viewed in the context of our complete study, it is not excluded that in this act, in parallel to the suggested martial level, also present in the past were the sexual aspects.

\section{Synthesis of the elements and interpretation of the action from the Odyssey}

Based on the analysis of the separate elements included in Odysseus's action of shooting an arrow through twelve axes, one can perceive the following possible meanings of this act.

It is fairly certain that it was not a plain wisecrack i.e. an improvisation by Odysseus aimed at proving his identity, but a ritual act that in the given time and culture was performed within the framework of marital ceremonies or the cyclical repetition of the rite of hierogamy. The two levels of the action are interwoven, whereby the hierogamy takes on the character of a cosmic model (first primordial marriage) conducted in "early mythical times" between the first divine couple (perhaps the Sky-God and the Earth-Goddess) or between the progenitor of a given culture (first man, first king) and the Great Goddess as the incarnation of earth, water, the whole universe or the specific land. It is quite possible that this ritual was performed periodically, every year or every few years, as a symbolic repetition of the cosmogonic act or as verification and validation of the masculinity, power and legitimacy of the ruler of the given land. Considering the connection of the labrys with the female deities of the given region and period, the arranged axes could have indicated the presence of the

\footnotetext{
${ }^{49}$ For the example (without the suggested meaning): Тановић 1940, 130.

${ }^{50}$ Basic facts about the ceremony: Sinjska alka 2020.
} 
Great Goddess in this act, whereby Odysseus take on the status of her divine husband, impregnator and son.

In the specific case, the entry of Odysseus into a symbolic marital union with this goddess could be a factor in his (re)legitimization, as master of his property, as ruler of Ithaca and as husband of Penelope, whereby she could also take on the meaning as an epiphany of the Great Goddess and of the land that he is meant rule once again.

The multiplicity of axes involved in this ritual could encode the time-related aspects of the benefits to which Odysseus aspires i.e. the duration of his reign over the next year, and possibly through all time that lies ahead in the future, just as the 12 months denote the whole year. The multiplication of axes can also have other meanings, among others and of "multitude of women" in a specific sense (multiple wives involved in his eventual polygamous marriage) or in a symbolic one - of Odysseus as master i.e. "husband" of all women belonging to the land i.e. the people that he is to rule.

It is obvious that in the specific plot of the Odyssey, this act is not included in its original meaning - as an element of the ritual system of the given culture, but as a dramatic element in service of the action. Odysseus, after many years, returns to his home where his status as a man, husband and progenitor is severely shaken by his long absence and suspicions that he is no longer alive. He performs the act of shooting an arrow through the axes in order to prove it i.e. to re-legitimize (in relation to Penelope's other suitors and contenders for his throne) his identity as her husband and to confirm his status as the master i.e. ruler of Ithaca. But, as we have said, the act of shooting an arrow through the axes is not some curiosity or his accidental wisecrack, for which the best evidence is the careful storage in his palace of all the equipment needed for its realization. This is another argument that it was in fact a ritual act that was performed regularly in the given environment or on certain occasions, probably at times when the husband and/or ruler had to periodically validate his status by repeating the marital i.e. the symbolic coitus (= hierogamy) with the Great Goddess (= paradigmatic woman).

Viewed from a literary i.e. narratological aspect, this act sets the true values of the characters involved in the given action, and especially of Odysseus in relation to the illegitimate suitors of Penelope. This act returns the indicated characters to their rightful place, thus reestablishing the original order in the given social environment (Odysseus' family and his kingdom).

The proposed symbolic, mythical and ritual character of Odysseus' arrow shooting leads us to reconsider the obsession of previous researchers with the real aspects of this action i.e. how it was realized and whether it was possible at all. Viewed in this context, the described act acquires the character of an ideal i.e. mythical paradigm that does not have to have a real basis at all, but quite the opposite - it should 
function as a challenge unachievable for the ordinary mortal, but achievable only to those of divine origin or significance.

As an additional confirmation of the suggested interpretations, but also of the inclusion of double axes in the arrow shooting by Odysseus, we can present another action from Homer's epics. This time it is the 23rd song from the "Iliad" where the funeral games in honor of Patroclus are sung, within which the warriors compete in archery. As the highest reward, Achilles promises double-edged axes ( $\delta \varepsilon \dot{\varepsilon} \kappa \alpha$ $\mu \varepsilon \dot{v} \pi \varepsilon \lambda \dot{\varepsilon} \kappa \varepsilon \alpha \varsigma)$ for the one who will hit with an arrow a turtle-dove ( $\tau \rho \dot{\eta} \rho \omega v a \pi \dot{\varepsilon} \lambda \varepsilon \imath \alpha v)$ tied to a rope, while as a second reward - ten oneedged axes $\left(\delta \dot{\varepsilon} \kappa \alpha \delta^{\prime} \eta^{\prime} \mu l \pi \varepsilon \lambda \dot{\varepsilon} \kappa \kappa \alpha\right)$ for the one who hits the rope to which the bird is tied. ${ }^{51}$ Although the basic components are here (shooting with a bow and arrow; the axe that is even double-edged), in this case the role as "symbol of the feminine" and "goal of the competition" is acquired by the bird, which in this context becomes very indicative considering that the name Penelope also has an "avian basis" i.e. it is a derivative of $\pi \eta v \varepsilon ́ \lambda o \psi$ with the meaning of wild duck or goose, which in Arcadia also appeared as a theonym of a local goddess. ${ }^{52}$ As good visual support for this interpretation and its obvious archetypal character we can present a Paleolithic petroglyph from Algeria, although it, in regards to the place and especially the time of its origin, seems very distant to the Odyssey and the action towards which our study was focused (Pl.V: 1). It shows a human (man, hunter) who tightens his bow and points an arrow towards a large bird, most likely an ostrich, while another human figure with outstretched arms stands behind him. The two figures are connected by a long line that starts from the genital area of the hunter, and ends with the crotch of the second figure. It is quite obvious that it signifies sexual contact i.e. the coitus between the two figures which, in turn, implies the female sex of the latter. This is supported by the pronounced width of her hips and even her outstretched arms, which can be backed up by numerous other similar compositions from this part of the world (mainly from the Predynastic Period in Egypt). This suggests that the same meaning of coitus is also encoded in a different way, by pointing the hunter's arrow at the bird, which gives it the character of a zoomorphic equivalent of the standing female figure. ${ }^{53}$

51 (Homeri Ilias 23.850-882); Венедиков 1987, 64, 65; Иванов 2012, 801.

52 In ancient times, the turtle-dove was the bird of love, dedicated to Aphrodite. In general on birds (non-predatory) as a female symbol (= bride, virgin): Маразов 2009, 82; Маразов 2006, 51, 52; on the name Penelope, with presented literature: Cook 1925, $691,692$.

${ }^{53}$ Neumann 1963, 114 -116, Fig. 11; Чаусидис 2017, 332-336 (В12), 353-357 (В20: $4,5,13)$. 


\section{CATALOGUE OF ILLUSTRATIONS}

Pl. I

1, 2. Stone mold for casting metal (detail), Minoan culture, Palaikastro, Crete, Greece. Photo: Nilsson1950, 225 - Fig. 112; Drawing: Müller-Karpe 1980, Taf. 219: E1.

3. Seal, Minoan/Mycenaean culture, Kalkani, Mycenae, Greece. Kalkani 2020.

4. Seal, Late Minoan period, Knossos, Crete, Greece. Haysom 2010, 40 - Fig. 1.

5. Seal, Minoan culture, Hagia Triada, Crete, Greece. Haysom 2010, 43 - Fig. 4.

6. Stone mold for casting metal (detail), Minoan culture, Palaikastro, Crete, Greece. MüllerKarpe 1980, Taf. 219: E2.

7. Seal, Minoan culture, Zakros, Crete, Greece. Haysom 2010, 43 - Fig. 5.

8. Seal, Minoan culture, Knossos, Crete, Greece. Haysom 2010, 44 - Fig. 7.

9. Ceramic idol, Geometric period, 9th century BCE, Boeotia, Greece. Boeotian bell-idol 2020.

10. Seal, Minoan culture, Terra, Greece. Haysom 2010, 44 - Fig. 6.

Pl. II

1. Coin of the city of Nysa (region of Caria), Asia Minor. Cook 1925, 564 - Fig. 452.

2. Coin of the city of Mostene (region of Lydia), Asia Minor. Cook 1925, 564 - Fig. 450.

3. Coin minted by Hadrian (Oxyrhynchite nome). Cook 1925, 626 - Fig. 530.

4. Bronze pendant-razor, Bronze Age, "Visoi", Beranci, Bitola, RN Macedonia. Garašanin 1983, T.CIX: 7.

5. Painted composition on a red-figured kylix ("Clytemnestra kills Cassandra"), c. 420 BCE, Spina, Archaeological Museum of Ferrara, Ferrara, Italy. Клитемнестра 2020.

6. Red-figured cup with a depiction of Clytemnestra (painter Brygos), 5th century BCE, Museo Nazionale di Spina, Italy. González \& Royo 2020.

7. Bronze pendant-razor, Bronze Age, Mesić, Vojvodina, Serbia. Трбуховић 1959, 198 - Сл. 1: 1 .

8. Motif from an Attic painted amphora, Late Geometric period, 730 - 720 BCE, National Archaeological Museum of Spain, Madrid, Spain. Prothesis 2020.

9. Ceramic idol, Geometric period, 9th century BCE, Boeotia, Greece. Baring \& Cashford 1993, 67 - Fig. 24.

Pl. III

1. Petroglyph, Neolithic period, Gobustan, Azerbaijan. Valou 1999, 18 - Sl. 19.

2. Heart pierced by an arrow, contemporary illustration. Corazon 2020.

3. Contemporary illustration of the story “The Frog Queen”. Царевна лягуика 2020.

4. Elongated plate of a two-plated bow fibula, 6th-7th century CE, schematic representation. Drawing: Чаусидис 2005a, B40: 12.

5. Fragmented fibula, 6th -7 th century CE, north Serbia. Werner 1950, Taf. 27: 2.

6. Motif carved in wood, ethnography, Podhale, Poland. Moszynski 1968, 137: 70.

7. Motif carved on a wooden distaff, ethnography, Mali Bukovec, Ludbreg, Croatia. KusNikolajev 1935, 25 - Sl. 6.

8. Icon of St. Marina with hagiography (detail), 18h century CE, Gallery of Icons, Ohrid, RN Macedonia. Георгиевски 1999, cat. no. 40.

9. Bronze relief plaque, Roman period, 3rd century CE, Pretor, Resen, RN Macedonia. Proeva 1983, Fig. 1 - b.

10. Painted ceramic vessel, Roman period, second half of the 3rd century CE, St. Matthias, Trier, Rheiniisches Landesmuseum, Trier, Germany. Trierer Göttervase 2020. 
11. Scene from an Attic red-figure amphora, c. 550 - 500 BCE, Kunsthistorisches Museum, Vienna, Austria. Dike 2014.

Pl. IV

1. The "double axe" or "hourglass" motif understood as a fusion of the two schematized halves of the female body. Drawing: Чаусидис 2017, 716 (Ѓ28: 2).

2. Bronze pendants, Bronze Age, Dobova, Bežice, Slovenia. Gabrovec 1983, T.VIII: 5 - 7.

3. Model of a double axe cast in bronze, undetermined dating and location of discovery (probably Bulgaria). Топалов 2010, 95 - Обр. 2.

4. Marble idol, undetermined dating, Danghan, Mazandaran, National Museum of Iran, Tehran, Iran. Idolo femenino 2020.

5. Ceramic idol, 2500 - 2000 BCE, Tepe-Hissar III Culture, Iran. Idole féminine 2020.

6. Motif carved on a ceramic vessel, Eneolithic period, Vučedol culture, Streimov Vinograd, Vučedol, Croatia. Hoti 1993, II, 2.

7, 8. Motifs painted on ceramic vessels, Eneolithic period, Cucuteni-Trypillia culture, Traian, Romania. Hoti 1993, II, 10.

9. Painted ceramic vessel, Eneolithic period, 3500 - 3000 BCE, cave Chiusazza, Syracuse, Sicily, Italy. Gimbutas 2001, 243 - Fig. 379.

10. Motif carved on a ceramic vessel, Neolithic period, Linear Pottery Culture, Czelevény, Hungary. Gimbutas 2001, 240 - Fig. 374: 1.

11. Icon of St. Marina, 18th century CE, Gallery of Icons, Ohrid, RN Macedonia. Георгиевски 1999, кат. бр. 42.

Pl. V

1. Petroglyph, Paleolithic period, Algeria. Neumann 1963, 114 - Fig. 11.

2. Motif from ornamentation of women's clothing (,kjurdia”), etnography, Shopsko Rudare, Kratovo, RN Macedonia. Ристовска Пиличкова 2012, 191, Б105: Сл. 1.

3. Motif from embroidered ornaments on a woman's apron, ethnography, surroundings of Kriva Palanka, RN Macedonia. The object is exhibited in the restaurant "Kaj Serdarot", at the Old Bazaar in Skopje, st. Kazandziska no. 5, Skopje, RN Macedonia. Photo: Jasminka Ristovska Pilichkova (Institute of Folklore „Marko Cepenkov”, Skopje).

4. Ceremonial competition "Sinjska alka", Sinj, Croatia. Sinjska (Pinterest) 2020.

5. The "double axe" or "hourglass" motif understood as two oppositely oriented vulvae. Scheme: Чаусидис 2017, 716 (Ѓ28: 1).

6. The motifs "double axe", "hourglass" and "hexagram" as geometric representations of hierogamy. Scheme: Чаусидис 2017, 718 (Ѓ29: 1-4).

Pl. VI

1. Stone axe, Eneolithic period, Korovci, Murska Sobota, Slovenia. Stalna 1997, 13.

2. Bone socket for a stone axe, Eneolithic period, Maliq, Албанија. Shqip. Arkeologike 1971, 13.

3. Stone axe-hammer, Bronze Age, Ingul and Catacomb cultures, Zamozhnoe, North Black Sea Region. Василенко et al 1987, 92 - Рис. 12: 4.

4. Stone axe-hammer, Bronze Age, Ingul and Catacomb cultures, Shyrokoe, North Black Sea Region. Василенко et al 1987, 92 - Рис. 12: 2.

5. Archaic technology for drilling openings in stone (schematic representation). Solenhofen 2020, Fig. 20.

6. Bronze pendant-razor, Bronze Age, Otok, Privlaka, Slavonija, Croatia. Vinski-Gasparini 1973, Tab. 28: 37. 
7. Bronze pendant-razor, Bronze Age, "Brodski Varoš", Slavonski Brod, Croatia. VinskiGasparini 1973, Tab. 56: 15.

8. Bronze object in the form of three double axes, Iron Age, Vergina, Greece. KilianDirlmeier 1979, Taf. 93: 1566.

9. Bronze set of three (?) double axes, Iron Age, "Sheste kukji", Tremnik, Negotino, RN Македонија. Георгиев 1987, 123 - Сл. 1-А.

Pl. VII

Graves and grave goods, Late Bronze - Early Iron Age, necropolis "Dimov Grob", Ulanci, Gradsko, RN Macedonia:

1. Set of double axes and glass paste beads, Grave 80. Videski 2007, 317 - Fig. 8.

2. Set of double axes and glass paste beads, Grave 54. Videski 2007, 317 - Fig. 7.

3, 4. Grave 54. Mitrevski 2006, 90 - Fig. 4.

5, 6. Grave 80. Mitrevski 2006, 90 - Fig. 4.

7. Bronze pendant, Iron Age, „Sheste kukji”, Tremnik, Negotino, RN Macedonia. Георгиев 1987, 123 - Сл. 1-Б.

8, 9. Bronze pendants, Grave 54. Videski 2007, 319 - Fig. 12.

\section{BIBLIOGRAPHY}

Анисимов, А. Ф. (1959). Космологические представления народов севера. Москва; Ленинград: Издательство академии наук СССР.

Baring, A. \& Cashford, J. (1993). The myth of the Goddess. Penguin Books, 1993.

Boeotian bell-idol (2020). "Boeotian bell-idol, Paris, Louvre". In Flickr $<$ http://www.flickr.com/photos/batigolix/455695326/> (29.09.2020)

Brain, P. \& Skinner, D. D. (1978) "Odysseus and the Axes: Homeric Ballistics Reconstructed," Greece \& Rome, 2nd Ser., Vol. 25, No. 1. pp. 55-58.

Царевна лягушка (2020). „Царевна лягушка”. In Vilingstore $<$ https://vilingstore.net/zhivotnye-nasekomye-rasteniya-flora-i-fauna/carevnalyagushka/> (28.09.2020)

Цивьян, Т. В. (1999). Движение и путь в балканской модели мира (исследования по структуре текста). Москва: Индрик.

Cook, A. B. (1925). Zeus: A Study in Ancient Religion. Vol. II. Cambridge: University Press.

Corazon (2020). "Corazon con flecha atravesada". In Imagui.com $<$ https://www.imagui.com/a/corazon-con-flecha-atravesada-TBXrB86gg $>$ (28.09.2020)

Чаусидис, Н. (1994). Митските слики на Јужните Словени. Скопје: Мисла.

Чаусидис, Н. (2005а). Космолошки слики (симболизаиија и митологизација на космосот во ликовниот медиум) Том I - II (Summary: N. Čausidis, Cosmological Images. Symbolisation and Mythologisation of the Cosmos in the Pictorial Medium). Скопје: Никос Чаусидис.

Чаусидис, Н. (2005b). „Археологија - ликовна семиотика - психологија (Интердисциплинарно согледување на феноменот 'преместување на либидото')” (Summary: N. Chausidis, Archaeology - Pictorial Semiotics - Archaeology, Interdisciplinary Perspective of Phenomenon "The Transfer of Libido"). In Научен собир 30 години Институт за психологија. Скопје: Филозофски факултет, pp. 133-156.

Чаусидис, Н. (2008). „Обредот како трансмисија меѓу половите нагони и работата”, Миф 14, pp. 5-43. 
Чаусидис, Н. (2009). „Сукња између жене и земље - дијахрони преглед семиотике покривања доњег дела женског тела" (Abstract: Nikos Chausidis, Skirt between woman and earth: a diachronic overview of the semiotics of covering the lower part of female body). In Д. Жунић (ed.), Традиционална естетска култура: тело и одевање. Ниш: Центар за научна истраживања САНУ и Универзитета у Нишу, pp. 202-233.

Чаусидис, Н. (2013). „Устата на кловнот и насмевката на Деметра-Баубо” (Summary: The Mouth of the Clown and the Smile of Demetra - Baubo). In B. Мартиновски, В. Томовска (eds.) Сите лица на смешното: од антиката до денес. Скопје: Друштво на класични филолози Антика; Друштво за компаративна книжевност на Македонија, pp. 55-73.

Чаусидис, Н. (2015). „Хиерогамија и њене ликовне претставе у древним и архаичним културама" (Summary: N. Chausidis, Pictorial representations of sacred marriage (hierogamy) in ancient and archaic cultures). In Д. Жунић (ed.) Традиционална естетска култура V: Ерос. Ниш: Центар за научна истраживања САНУ и Универзитета у Нишу, pp. 44-109.

Чаусидис, Н. (2017). Македонските бронзи и митологијата и религијата на железнодобните заедниии од Средниот Балкан (Summary: N. Chausidis, Macedonian bronzes and the religion and mythology of Iron Age communities in the Central Balkans). Скопје: Центар за истражување на предисторијата. (digital edition)

Чаусидис, Н. (2020) „Архаични форми на симболизација на логосот” (Abstract: Archaic

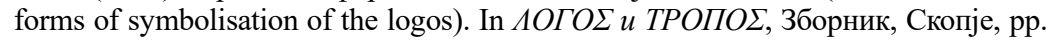
37-70. (in print)

Чеха, О. В. (2012). „Топор”. In Т. А. Агапкина et al (eds.), Славянские древности (Этнолингвистический словарь) Том 5. Москва: Международные отношения, рр. 288-290.

Dike (2020). "Dike". In Theoi Greek Mythology. Exploring Mythology in Classical Literature and Art $<\mathrm{http}: / /$ www.theoi.com/Ouranios/HoraDike.html $>$ (29.09.2020)

Драгојевиќ-Јосифовска, Б. (1981). „Жртвеник од SCVPI, посветен на божицата Bellona", Жива антика 31, pp. 181-185.

Ефтимовски, И. (2020). Примената на методот на симболичка анализа во интерпретацијата на археолошките наоди кои отсликуваат антропоморфизиран круг (магистерски труд). Скопје: Филозофски факултет.

Elijade, M. (1983) Kovači i alkemičari (M. Eliade, Forgerons et alchimiste). Zagreb: GZH.

Gabrovec, S. (1983). „Jugoističnoalpska regija”. In Praistorija Jugoslovenskih zemalja Tom IV (Bronzano doba). Sarajevo: Akademija nauka i umjetnosti Bosne i Hercegovine Centar za balkanološka ispitivanja,pp. 21-96.

Георгиева, И. (1983). Българска народна митология. София: Наука и изкуство.

Garašanin, M. (1983).”Razvijeno bronzano doba I. Prelazni period (Gvozdeno doba I) Makedonije". In Praistorija Jugoslovenskih zemalja, Tom IV (Bronzano doba). Sarajevo: Akademija nauka i umjetnosti Bosne i Hercegovine - Centar za balkanološka ispitivanja.

Георгиев, 3. (1987). „Необјавени и нови наоди од Повардарието”, Годишен зборник на Филозофскиот факултет 14 (40), 117-134.

Георгиевски, М. (1999). Галерија на икони - Охрид. Охрид: Завод за заштита на спомениците на културата и Народен музеј - Охрид.

González, S. G. \& Royo, S. O. (2020). Clitemnestra. Índice de contenidos $<$ https://fradive.webs.ull.es/sem/clitemnestradef.htm> (29.09.2020)

Gimbutas, M. (1973). "Perkūnas/Perun: The Thunder God of the Balts and the Slavs", The Journal at Indo-European Studies 1, pp. 466-478.

Gimbutas, M. (2001). The Language of the Goddess. New York: Thames \& Hudson, 2001.

Gluhak, A. (1993). Hrvatski etimološki rječnik. Zagreb: August Cesarec. 
Hatzopoulos, M. (1987). “Artémis Digaia Blaganitis en Macédoine”, Buletin de correspondance hellénique 111.1, pp. 397-412.

Haysom M. (2010). "The Double-Axe: A Contextual Approach to the Understanding of a Cretan Symbol in ihe Neopalatial Period", Oxford Journal of Archaeology 29.1, pp. 35-55.

Hoti, M. (1993). Prethistorijski korjeni nekih aspekata grčke religije (doctoral dissertation manuscript). Zagreb: Filozofski fakultet.

Idole féminine (2020). "Idole féminine, culture de Tépé-Hissar, Iran, région nord-es". In Musée Barbier-Mueller <http://barbier-mueller.ch/collections/antiquite/art-des-cyclades-et-apparente-aux/?lang=fr> (29.09.2020)

Idolo femenino (2020). "Idolo femenino, en Marmol, Hallado en Danghan, Mazandaran". In Pineterst $<$ https://www.pinterest.com/pin/49891508345447694/> (25.09.2020)

Иорданский, В. Б. (1981). Звери, люди, боги - очерки африканской мифологии. Москва: Наука.

Иванов, Я. (2012). „Лабрисът в защитното въоръжение от Тракия. Шлемът от Пастуша". In К. Рабаджиев et al (eds.), Изкуство \& идеология. София: Университетско Издателство „Св. Климент Охридски”, pp.792-810.

Kalkani (2020)."157365: Siegel CMS I 144. Mykenai, Mykene, Nekropole Kalkani S Bank." In Idai.imagesArachne <http://arachne.uni-koeln.de/arachne/index.php?view [layout] $=$ objekt_item\&search[constraints][objekt][searchSeriennummer] $=157365>$ (26.07.2020)

Kilian-Dirlmeier, I. (1979). Anhanger in Griechenland von der mykenischen bis zur spatgeometrischen Zeit: (griechisches Festland, Ionische Inseln, dazu Albanien und Jugoslawisch Mazedonien). Prahistorische Bronzefunde. Munchen: Beck.

Кличкова, В. (1963). Македонски народни носии, Скопје: Етнолошки музеј.

Клитемнестра (2020). „Клитемнестра убивает пленницу Агамемнона Кассандру”. In Мега Енциклопедија Кирилла и Мефодия <http://megabook.ru/media/Клитемнестра («Клитемнестра убивает Кассандру»)> (29.09.2020)

Колева, Т. (1967). „По някои въпроси от проблематиката на южнославянските обичаи при сеитба", Известия на етнографския институт и музей X, pp. 173-200.

Kus-Nikolajev, M. (1935). "Seljačka ornamentika (Prilog sociologiji jugoslovenske seljačke umetnosti)", Vjesnik etnografskog muzeja u Zagrebu I (sv. 1, 2), pp. 15-48.

Малинова, Р. \& Малин, Я. (1988). Прыжок в прошлое (эксперимент раскрывает, тайны древних эпох). Москва: Мысль.

Маразов, И. (2006). „Богинята Атина в царската идеология на древна Тракия”. In Проблеми и изследвания на тракийската култура Том І. Казанльк: Ирита, pp. 3873.

Маразов, И. (2009). Хубавата Елена между Троя и Тракия. София: „Захарий Стоянов”.

Matić, V. (1979). Psihoanaliza mitske prošlosti. Tom II. Beograd: Prosveta.

Mitrevski, D. (2006). "Genesis of the Iron Age Culture in Macedonia", Folia archaeologica Balkanica 1, pp. 85-96.

Mitrevski, D. (2010). "On the Ethno-Cultural Basis of Ancient Macedonia", Macedonian Historical Review 1, pp. 9-24.

Митревски, Д. (1997). Протоисториските заедници во Македонија: преку погребуваюето и погребните манифестащии. Скопје: Републички завод за заштита на спомениците на културата.

Мороз, Й. (1989). „Към въпроса за семантиката на лъка и стрелата при древните българи". In Проблеми на прабългарската история и култура. Том 1. София: БАН, pp. 448-458.

Moszynski, K. (1968). Kultura ludova Slowian T. II/2. Warszawa: Ksiąźka i Wiedza, 1968.

Müller-Karpe, H. (1980). Handbuch der Vorgeschichte. München: C.H. Beck. 
Neumann, E. (1963). The Great Mother - an analysis of the archetype. Princeton University Press.

Nilsson, M. P. (1950). The Minoan-Mycenaean Religion and Its Survival in Greek Religion (Second Revised Edition). Biblo and Tannen.

Papazovska A. (2018). "Double Axe or Labrys in the Grave Context - Ritual Object or Ceremonial Symbol?". In D. Gjeorgijevski (ed.), Kokino - Giving Gifts to God: Evidence of Votive Offerings in the Sanctuaries, Temples and Churches. Kumanovo: National Institution Museum of Kumanovo, pp. 119-130.

Папазовска Санев А. (2015). Раното железно време во Република Македонија (doctoral dissertation manuscript), Скопје: Филозофски факултет.

Pocock, L. G. (1961). "The Arrow and the Axe-Heads in the Odyssey", The American Journal of Philology 82. 4, pp. 346-357.

Proeva, N. (1983). "La déesse cappadocienne Mâ et son culte en Macédoine d'après une plaque en bronze de Pretor au Musée de Resen”, Жива Антика 33.2., pp. 165-183.

Проева, Н. (2014). Религијата на античките Македоничи. Скопје: Графотиск.

Prothesis (2020). "Prothesis scene LGIIa MAN Inv1999-99-26.jpg". In Wikimedia Commons, the free media repository $<$ https://commons.wikimedia.org/wiki/ File: Prothesis_scene_LGIIa_MAN_Inv1999-99-26.jpg $>(29.09 .2020)$

Ристовска Пиличкова, J. (2012). Македонската традиционална текстилна орнаментика - класификаиија, типологија, и семиотика на ликовните елементи (doctoral dissertation manuscript). Скопје: Институт за фолклор „Марко Цепенков”.

Russo, C. J. (2004). "Odysseus' Trial of the Bow as Symbolic Performance”. In A. Bierl et al (eds.) Antike Literatur in neuer Deutung. Leipzig - München: K. G. Saur, pp. 95101.

Савостина, Е. А. (1983). „К символике изображения лука на Боспоре”, Советская археология $1983 / 4$, pp. 45-56.

Shqip. Arkeologike (1971). Shqiperia arkeologike. Tiranë: Universiteti shteteror - Instituti i historise i gjuhesise.

Sinjska alka (2020). "Sinjska alka". In Wikipedia, the free encyclopedia <https://en. wikipedia.org/wiki/Sinjska_alka> (27.09.2020)

Sinjska (Pinterest) (2020). "Sinjska alka". In Pinterest <https://www.pinterest.com/pin/ 398005685799824836/?nic_v2=1adPYD0A8> (26.09.2020)

Skok, P. (1974). Etimologijski rječnik hrvatskoga ili srpskoga jezika. Zagreb: Jugoslovenska akademija znanosti i umjetnosti.

Solenhofen, A. (2020). "Ancient Egyptian Stoneworking Tools and Methods". In Unforbidden geology. The not so hidden history of Man from the often overlooked geologic perspective

$<$ http://www.oocities.org/unforbidden_geology/ancient_egyptian_copper_coring_dri 1ls.html $>(27.09 .2020)$

Stalna (1997). Stalna razstava - Pokrainski muzej Murska Sobota, Murska Sobota.

Stanford, W. B. (1949). "A Reconsideration of the Problem of the Axes in Odyssey XXI", The Classical Review 63. 1, pp. 3-6.

Станилов, С. (1981). „Семантиката на лька и стрелата в изображенията от ранносредновековна България”, Археология 1981/1-2, pp. 28-36.

Stefanidou, V. (2008). "Ma". In Encyclopaedia of the Hellenic World, Asia Minor. <http:// www.ehw.gr/l.aspx?id=7736> $(27.09 .2020)$

Тановић, С. (1940). „Огништа и `димници` из околине Ђевђелије”, Гласник скопског научног друштва XXI, , pp. 123-136.

Топалов, С. (2010). „Принос към проучването на тракийските култови бронзови брадвички", Миф 15, pp. 92-105.

Трбуховић, В. (1959). „Прилог проучавању Халштатске културе у средњем Подунављу”, Старинар IX - Х. Београд, pp. 197-201. 
Trierer Göttervase (2020). "Trierer Göttervase". In Rheinisches Landesmuseum Trier $<$ http://www.landesmuseum-trier.de/en/home/dauerausstellung/bildergalerie-ausstellungsstuecke.html $>(27.09 .2020)$

Василенко, А. И., Блюм, Т. В. \& Ветров, В. С. (2007). „О древних каменных стелах из окрестностей села Пархоменко Краснодонского района Луганщины”. In Искусство и религия древних обществ. Луганск: Світлиця, pp. 72-105.

Венедиков, И. (1987). Златният стожер на Пра-българите. София: Наука и изкуство.

Valou, D. (1999). "Prazgodovinska domišljija", Glasnik Unesco 52, pp. 18-23.

Videski, Z. (2007). "Religious Beliefs of the Late Bronze Age in the Territory of the Republic of Macedonia". In Scripta praehistorica in honorem Biba Teržan, Situla, 44, Dissertationes Musei Nationalais Sloveniae. Ljubljana, pp. 313-320.

Vinski-Gasparini K. (1973). Kultura polja sa žarama u sjevernoj Hrvatskoj. Zadar: Filozofski fakultet.

Werner, J. (1950). „Slawischen Bügelfibeln des 7. Jahrhunderts”. In Reinecke - Festschrift. Mainz, pp. 150-172.

Зарубин, И. И. (1925). „Дополнения к статье Н. И. Веселовского «Роль стрелы в обрядах и ее символическое значение»“. In Записки Коллегии Востоковедов при Азиатском Музее Российской Академии Наук. Том І. Ленинград: РАН, Главнаука, Госиздат, pp. 91-96. 